\title{
Spathodea campanulata P. Beauv. - A review of its ethnomedicinal, phytochemical, and pharmacological profile
}

\author{
Gopal Krishan Padhy* \\ Department of Pharmaceutical Chemistry, School of Pharmacy, Centurion University of Technology and Management, Odisha, India.
}

\begin{tabular}{l}
\hline ARTICLE INFO \\
\hline Received on: $19 / 06 / 2021$ \\
Accepted on: $24 / 08 / 2021$ \\
Available Online: $05 / 12 / 2021$ \\
\\
\hline Key words: \\
Spathodea campanulata, \\
Bignoniaceae, ethnomedicine, \\
phytochemical, pharmacology.
\end{tabular}

\section{INTRODUCTION}

Humans have been conscious of the therapeutic potential of plants since ancient times. Almost every indigenous culture of humankind makes use of various medicinal plants for curing ailments. Ethnopharmacological knowledge is practiced amid the tribal population, but a great deal of this knowledge is pragmatic

\footnotetext{
*Corresponding Author

Gopal Krishan Padhy, School of Pharmacy, Centurion University of Technology and Management, Rayagada, India.E-mail: gopalmedchem@ gmail.com
}

\begin{abstract}
Spathodea campanulata P. Beauv., belonging to the family Bignoniaceae, is a big erect tree with an ancient history of medicinal use in Africa. In the traditional system, it is mentioned for the treatment of malaria, diabetes, stomach ulcers, wounds, skin infections and viral diseases. The aim of the review is to make available the current information that exists on the traditional uses, phytochemistry, pharmacology, and toxicology of $S$. campanulata. Additionally, the potential uses of this plant to treat various diseases and to bring in a foundation for further research are emphasized. The present review is carried out by compiling literature from 1972 to 2021, concerning the morphology, traditional uses, phytochemistry, pharmacological activities, and toxicological aspects of $S$. campanulata. Literatures were collected from various online search engines, viz. Google Scholar, PubMed, Science Direct, Core, and Semantic Scholar. Diverse chemical compounds including iridoids, terpenoids, steroids, cinnamic acid derivatives, cerebrosides, flavonoids, and carotenoids have been isolated from this plant. Mostly in-vivo models have indicated several evidences of the use of this plant particularly to cure malaria. Few in-vivo studies have also proved the usefulness of this plant in inflammation, wound healing, diabetes, and convulsion. In some in-vitro studies, the anticancer, antibacterial, antiviral insecticidal, larvicidal, and anti-oxidant potential has been proved. Preclinical studies have demonstrated remarkable activity which supports the conventional use of the plant as an antimalarial, wound healing, antidiabetic, antimicrobial, and anti-inflammatory agent for years without any adverse effects. Based on the results obtained from a combination of in vivo and in vitro potency and toxicity studies reported, S. campanulata is a promising agent in the development of nutraceuticals against malaria and diabetes. Although few phytochemicals isolated (ursolic acid, tomentosolic acid, 20 $\beta$-hydroxyursolic acid, verminoside, specioside, spathoside, kaempferol, and $\beta$-sitosterol-3-acetate) from the plant exhibited remarkable biological activity, it was only confined to preclinical study. The only clinical study documented is for curing malaria, but with crude extract only. With its current extensive traditional use, there is a need for additional studies of the isolated compounds, clinical trials, and product development to take full advantage of this widely distributed medicinal plant.
\end{abstract}


the foothills and forests of the Africa prescribed this plant for the treatment of malaria (Adebayo and Krettli, 2011; Komlaga et al., 2015; Osei-Djarbeng et al., 2015), diabetes (Tsabang et al., 2017), dysentery, asthma, stomach ache (Tugume and Nyakoojo, 2019a), fever (Emmanuel and Didier, 2012), and fungal and bacterial infections (Kamatenesi-Mugisha et al., 2008). There has been great interest in $S$. campanulata, as evidenced by the many works carried out in recent years (references therein). Hence, it is worth updating the association between the traditional uses and the current pharmacology of $S$. campanulata, as has been carried out for numerous plants. This review is intended to provide up-to-date information about the ethnopharmacological uses, photochemistry, pharmacological potential, and toxicity profile of this useful plant. It will provide dimensions to researchers who are willing to explore the plant further. It will enable traditional practitioners to promote the use a holistic approach of considering traditional and current medicine.

\section{REVIEW METHODOLOGY}

The literatures reviewed were collected using a systematic and comprehensive literature search on the medicinal plant $S$. campanulata. The articles were collected from various online search engines, viz. Google Scholar, PubMed, Science Direct, Core, and Semantic Scholar. Keyword combinations undertaken for the searches were Spathodea campanulata along with ethnomedicinal use or chemical constituent or pharmacology or bioactive compounds. Two chief criteria were employed for the collection of appropriate references for this review. For ethnomedicinal uses, all articles that were accessible with any relevant information on the ethnomedicinal and ethnoveterinary uses of $S$. campanulata were considered. Limitations to the journal of standard were not considered because the bulk of the publications are generally centered on the records of oral traditions. In observation to the claimed ethnomedicinal uses of $S$. campanulata, the papers that correlated with the disease description and validated by various biological studies were selected. Google Scholar provided about 6,470 search results for keyword S. campanulata, but around $80 \%-90 \%$ of the articles suggested were out of theme. Only about $10 \%-20 \%$ of the articles recommended were practical, out of which 182 references were used for this review. During the search, two compositions published earlier came to limelight (Boniface, 2017; Wagh and Butle, 2018). However, none of the reviews were comprehensive in nature. This review is proposed to make available the recent information on customary and local knowledge, classification of biologically important molecules, and pharmacological studies accomplished for validation of traditional use.

\section{BOTANICAL DESCRIPTION AND VERNACULAR NAMES}

The African tulip tree is a big erect tree with lustrous greenish pinnate leaves and wonderful reddish orange flowers. It can grow to up to 80 feet in suitable conditions. It has a solid trunk enclosed with a light gray bark. The leaves are usually opposite up to $10-15 \mathrm{~cm}$ long, elliptic to oblong, and are assembled at the branch's tips. The leaves are compound, imparipinnate with seven to eight pairs of leaflets, and a 5-6 cm long petiole. Oval leaflets contain seven to eight major deep veins on each side. Horn-shaped silky buds emerge upside down at the end of the branch. The buds are filled with water and are frequently used by small children as "mini squirt-guns." The blooms are big and cup-like with a brilliant reddish orange color. The fruits are 5-10 inches long, finger-like, $16 \mathrm{~cm}$ long, and points upward. Each fruit contains about 500 paper-like seeds. The tree blooms usually in the spring (CABI, 2021; Flowers of India, 2021; Sonibare and Osiyemi, 2012). The vernacular names of $S$. campanulata are mentioned in Table 1.

\section{DISTRIBUTION}

It is distributed worldwide, but most of them occur in the tropical and sub-tropical countries. It is native of Africa (i.e., in Angola, Burundi, Benin, Cameroon, Equatorial Guinea, Ghana, Gabon, Guinea, Nigeria, Liberia, Sierra Leone, Rwanda, Togo, and Zambia). It was introduced in Australia, Brazil, China, Costa Rica, Cuba, Egypt, French Guiana, French Polynesia, India, Indonesia, Kenya, Jamaica, Malaysia, Madagascar, Mexico, Papua New Guinea, Peru, Puerto Rico, Singapore, Saint Lucia, Sri Lanka, Spain, Thailand, United States (Hawaiian Is., Florida), Venezuela, and British Virgin Islands (IUCN, 2020). Spathodea campanulata has become an invasive species and has a threatened biodiversity in the Pacific islands. It has impacted the economy, cultural, and social welfare of pacific peoples (Brown and Daigneault, 2014; Labrada and Medina, 2009). It has invaded the discarded agricultural lands and jungle, and has become a dominant weed in Puerto Rico (Rivera and Aide, 1998). It is considered as a weed in the coffee orchards of Cuba (Herrera et al., 2002).

\section{ETHNOMEDICINAL USE}

A wide range of traditional uses are cited in the literature for $S$. campanulata. The stem bark of $S$. campanulata is mainly used in Africa to treat malaria (Iyamah and Idu, 2015). The leaves are used in India and Africa to treat skin disorders (Kumar and Dash, 2012; Shehu et al., 2018). The leaf is also used to treat epilepsy (Noumi and Fozi, 2003), liver disorder (Shiracko et al., 2016), asthma (Nwauzoma and Dappa, 2013), measles (Oladunmoye et al., 2011), and sore throat (Shiracko et al., 2016). The root is used for worm infections (Musinguzi et al., 2017), stomach ache (Musinguzi et al., 2017), dysentery (Tabuti et al., 2003), and hallucination (Ior et al., 2017). The flower is used as an antidote against animal poison (Santosh et al., 2019) and cataract (Tewari et al., 2019). Of the traditional uses cited, the most common conditions treated is malaria (11 articles), gastrointestinal tract (GIT) problem (9 articles), skin infections (7 articles), wound healing (6 articles), and kidney problem (4 articles). Traditional uses mostly employed the bark of the plant. The leaf and whole plant are also cited, but less frequently. The plant is used alone or in combination with other medicinal plants. Table 2 summarizes the various traditional uses of $S$. campanulata.

\section{PHYTOCHEMICAL STUDIES}

Exhaustive phytochemical investigations of various parts of $S$. campanulata lead to the isolation of many secondary metabolites such as iridoids (Fig. 1), triterpenoids (Fig. 2), sterol and cerebrosides (Fig. 3), and flavonoids (Figs. 4 and 5). Iridoids are the most important phytochemicals 
Table 1. Vernacular names of $S$. campanulate.

\begin{tabular}{ccc}
\hline S.N. & Language & Vernacular name \\
\hline 1 & English & Flame of the forest, tulip tree \\
2 & India & Rugtoora (Hindi), patadi(Tamil), nandi flame \\
3 & Spanish & Tulipanero de Gabon, llama del bosque \\
4 & French & Baton du sorcier, tulipier d'Afrique \\
5 & German & Afrikanischer Tulpenbaum \\
6 & Chinese & Neerukayi maru \\
7 & Srilanka & Kudaella gaha \\
8 & Spain & Tulipanero de Gabon \\
9 & Malaysia & Panchut-panchut \\
10 & Mexico & Tulipero de Gabon \\
11 & Brazil & Ttulipero-africano, arvore-da-bisnaga; bisnagueira, \\
12 & African countries & Kibobakasi; kifabakazi; sebetaiyet (Uganda), \\
\end{tabular}

Table 2. Ethnomedicinal uses of $S$. campanulate.

\begin{tabular}{|c|c|c|c|c|c|c|}
\hline S.N. & Disease & $\begin{array}{l}\text { Plant } \\
\text { parts }\end{array}$ & Method of administration & Local name & Place & Ref. \\
\hline \multirow[t]{11}{*}{1} & Malaria & $\mathrm{L}$ & Decoction/infusion is orally taken & Cifulafula & $\begin{array}{l}\text { Bukavu and Uvira, } \\
\text { DR Congo }\end{array}$ & Manya et al., 2020 \\
\hline & & $\mathrm{L}, \mathrm{SB}$ & Decoction is orally taken & Kuakuanisuo & Ejisu-Juaben, Ghana & Appiah et al., 2019 \\
\hline & & $\mathrm{L}, \mathrm{SB}$ & Decoction is orally taken & Not stated & Abidjan, West Africa & $\begin{array}{l}\text { Offoumou et al., } \\
2017\end{array}$ \\
\hline & & SB & Decoction is orally taken & Mutsulio & Kakamega, Kenya & Mukungu et al., 2016 \\
\hline & & SB & $\begin{array}{c}\text { Decoction is used orally, as enema } \\
\text { and for bathing. Body is smeared } \\
\text { with bark pulp }\end{array}$ & Not stated & $\begin{array}{l}\text { Aby Lagoon, Cote } \\
\text { d'Ivoire }\end{array}$ & Malan et al., 2015 \\
\hline & & SB & Decoction is orally taken & Oruru, mojutoro & Southern Nigeria & $\begin{array}{l}\text { Iyamah and Idu, } \\
2015\end{array}$ \\
\hline & & $\mathrm{S}$ and $\mathrm{R}$ & Decoction is orally taken & Kookoo nisuo & Southern Ghana & $\begin{array}{l}\text { Asase and Oppong- } \\
\text { Mensah, } 2009\end{array}$ \\
\hline & & B & $\begin{array}{l}\text { Decoction is used orally thrice a } \\
\text { day for } 5 \text { days. }\end{array}$ & Kifabakazi & Uganda & Adia et al., 2014 \\
\hline & & $\mathrm{F}, \mathrm{L}$ & $\begin{array}{l}\text { Juice is warmed on fire and taken } \\
\text { orally with morinda }\end{array}$ & Not stated & $\begin{array}{l}\text { Savana margin area, } \\
\text { Cameroon }\end{array}$ & $\begin{array}{l}\text { Betti et al., } \\
2013\end{array}$ \\
\hline & & $\mathrm{L}, \mathrm{SB}$ & Not stated & Not stated & Cameroon & Titanji et al., 2008 \\
\hline & & $\mathrm{L} / \mathrm{SB}$ & $\begin{array}{l}\text { Decoctions and concoctions is } \\
\text { orally taken }\end{array}$ & Not stated & Northwest Cameroon & Focho et al., 2009a \\
\hline 2 & Schistosomiasis & $\mathrm{L}$ & Decoction/infusion is orally taken & Cifulafula & $\begin{array}{l}\text { Bukavu and Uvira, } \\
\text { DR Congo }\end{array}$ & Manya et al., 2020 \\
\hline \multirow[t]{2}{*}{3} & Typhoid & $\mathrm{L}, \mathrm{SB}$ & Decoction is orally taken & Kuakuanisuo & Ejisu-Juaben, Ghana & Appiah et al., 2019 \\
\hline & & $\mathrm{B}, \mathrm{L}$ & Decoction, Maceration & $\begin{array}{l}\text { Foufougue } \\
\text { Foukfouk }\end{array}$ & Western Cameroon & Tsobou et al., 2013 \\
\hline 4 & Gastric ulcer & S & $\begin{array}{c}\text { Decoction } \\
\text { Enema }\end{array}$ & Kwekwemunsu & $\begin{array}{l}\text { Accra metropolis, } \\
\text { Ghana }\end{array}$ & Bekoe et al., 2020 \\
\hline
\end{tabular}




\begin{tabular}{|c|c|c|c|c|c|c|}
\hline S.N. & Disease & $\begin{array}{l}\text { Plant } \\
\text { parts }\end{array}$ & Method of administration & Local name & Place & Ref. \\
\hline \multirow[b]{5}{*}{5} & & B & Decoction & Kifabakazi/ & Uganda & Anywar et al., 2020 \\
\hline & & & & Shitsubi & & \\
\hline & & $\mathrm{R}, \mathrm{SB}$ & Not stated & Ruuru & $\begin{array}{l}\text { South-western } \\
\text { Nigeria }\end{array}$ & $\begin{array}{l}\text { Akinwumi and } \\
\text { Sonibare, } 2019\end{array}$ \\
\hline & & $\mathrm{L}, \mathrm{SB}$ & Decoction & Kuokuonesuo & $\begin{array}{l}\text { Bosomtwi-Atwima- } \\
\text { Kwanwoma, Ghana }\end{array}$ & Agyare et al., 2009 \\
\hline & \multirow[t]{3}{*}{ Stomach ache } & $\begin{array}{l}\mathrm{R}, \mathrm{SB} \\
\mathrm{F}, \mathrm{S}\end{array}$ & Not stated & $\begin{array}{l}\text { Omunyara/ } \\
\text { Ekifabakazi }\end{array}$ & Western Uganda & $\begin{array}{l}\text { Musinguzi et al., } \\
2017\end{array}$ \\
\hline & & $\mathrm{L}$ & Not stated & Omutsurio & Kenya & Shiracko et al., 2016 \\
\hline & & $\mathrm{L} / \mathrm{B}$ & $\begin{array}{l}\text { Decoction/infusion taken orally or } \\
\text { applied topically }\end{array}$ & Not stated & Western Kenya & Omale et al., 2020 \\
\hline \multirow[t]{2}{*}{6} & \multirow[t]{2}{*}{ GIT troubles } & $\mathrm{B} / \mathrm{L}$ & Infusion & $\begin{array}{l}\text { Ucche kayi } \\
\text { mara }\end{array}$ & Karnataka, India & $\begin{array}{l}\text { Prashanth Kumar } \\
\quad \text { et al., } 2016\end{array}$ \\
\hline & & B & Decoction & Not stated & $\begin{array}{l}\text { Democratic Republic } \\
\text { of the Congo }\end{array}$ & $\begin{array}{l}\text { Terashima and } \\
\text { Malasi, } 1991\end{array}$ \\
\hline 7 & Appetizer & $\mathrm{L} / \mathrm{B}$ & $\begin{array}{l}\text { Decoction/infusion orally taken } \\
\text { orally }\end{array}$ & Not stated & Western Kenya & Omale et al., 2020 \\
\hline \multirow[t]{3}{*}{8} & \multirow[t]{3}{*}{$\begin{array}{l}\text { Kidney diseases and } \\
\text { urethra inflammations }\end{array}$} & SB & Not stated & Patida & $\begin{array}{l}\text { Khammam District, } \\
\text { Telangana, India }\end{array}$ & $\begin{array}{l}\text { Priyadarshini and } \\
\text { Ragan, } 2019\end{array}$ \\
\hline & & $\mathrm{B} / \mathrm{L}$ & Infusion & $\begin{array}{l}\text { Ucche kayi } \\
\text { mara }\end{array}$ & Karnataka, India & $\begin{array}{l}\text { Prashanth Kumar } \\
\quad \text { et al., } 2016\end{array}$ \\
\hline & & $\mathrm{F} / \mathrm{SB} / \mathrm{L}$ & Not stated & Not stated & India & Santosh et al., 2019 \\
\hline 9 & $\begin{array}{l}\text { Urinary tract infections } \\
\text { and gonorrhea }\end{array}$ & B & $\begin{array}{c}\text { Decoction (Oral and parenteral } \\
\text { feeding) }\end{array}$ & $\begin{array}{c}\text { Cifulula/Langalanga } \\
\text { Mbalimbali }\end{array}$ & $\begin{array}{l}\text { Bukavu city, D.R. } \\
\text { Congo }\end{array}$ & Mahanoa et al., 2013 \\
\hline 10 & Liver disorder & $\mathrm{L}$ & Not stated & Omutsurio & Kenya & Shiracko et al., 2016 \\
\hline \multirow[t]{3}{*}{11} & \multirow[t]{3}{*}{ Dysentery } & $\mathrm{B} / \mathrm{L}$ & Infusion & $\begin{array}{l}\text { Ucche kayi } \\
\text { mara }\end{array}$ & Karnataka, India & $\begin{array}{l}\text { Prashanth Kumar } \\
\quad \text { et al., } 2016\end{array}$ \\
\hline & & B & Paste & Rugtoora & Uttar Pradesh, India & Shukla et al., 2014 \\
\hline & & $\mathrm{R}$ & $\begin{array}{l}\text { Decoction drunk } \\
\text { Wash patient }\end{array}$ & Not stated & Bulamogi, Uganda & Tabuti et al., 2003 \\
\hline 12 & Worms infection & $\begin{array}{l}\mathrm{R}, \mathrm{SB} \\
\mathrm{F}, \mathrm{S}\end{array}$ & Not stated & $\begin{array}{l}\text { Omunyara/ } \\
\text { Ekifabakazi }\end{array}$ & Western Uganda & $\begin{array}{l}\text { Musinguzi et al., } \\
2017\end{array}$ \\
\hline \multirow[t]{2}{*}{13} & $\begin{array}{c}\text { Backache, headache and } \\
\text { ear pains }\end{array}$ & $\begin{array}{l}\mathrm{R}, \mathrm{SB} \\
\mathrm{F}, \mathrm{S}\end{array}$ & Not stated & $\begin{array}{l}\text { Omunyara/ } \\
\text { Ekifabakazi }\end{array}$ & Western Uganda & $\begin{array}{l}\text { Musinguzi et al., } \\
2017\end{array}$ \\
\hline & backache & $\mathrm{R}$ & $\begin{array}{l}\text { Decoction prepared from root } \\
\text { powder of } S \text {. campanulata, Tragia } \\
\text { furialis, Carisa spinarum and } \\
\text { Buchananii was taken orally }\end{array}$ & Not stated & $\begin{array}{l}\text { Bukoba District, } \\
\text { Western Tanzania }\end{array}$ & Moshi et al., 2010 \\
\hline 14 & Severe headache & $\mathrm{L}$ & Not stated & Omutsurio & Kenya & Shiracko et al., 2016 \\
\hline \multirow[t]{2}{*}{15} & Diabetes & $\mathrm{L}$ & Decoction & Soukounden & Guinea, West africa & Diallo et al., 2012 \\
\hline & & SB & Decoction & Not stated & $\begin{array}{l}\text { Agboville, South- } \\
\text { eastern Ivory Coast }\end{array}$ & Koffi et al., 2009 \\
\hline 16 & Cataract & $\mathrm{F}$ & Flower exudate, 0.1 and $0.2 \mathrm{mg} / \mathrm{ml}$ & Not stated & India & Tewari., 2019 \\
\hline 17 & Chest pain & $\mathrm{L} / \mathrm{B}$ & $\begin{array}{l}\text { Decoction/infusion orally taken } \\
\text { orally }\end{array}$ & Not stated & Western Kenya & Omale et al., 2020 \\
\hline
\end{tabular}




\begin{tabular}{|c|c|c|c|c|c|c|}
\hline S.N. & Disease & $\begin{array}{l}\text { Plant } \\
\text { parts }\end{array}$ & Method of administration & Local name & Place & Ref. \\
\hline & & B & Decoction & $\begin{array}{c}\text { Kifabakazi / } \\
\text { Shitsubi }\end{array}$ & Uganda & Anywar et al., 2020 \\
\hline 18 & Hallucination & $\mathrm{L}, \mathrm{R}$ & Oral infusion/bathing & Aduruku & Plateau State, Nigeria & Ior et al., 2017 \\
\hline 19 & Mental disorders & $\mathrm{L}, \mathrm{SB}$ & $\begin{array}{l}\text { Decoctions and concoctions is } \\
\text { orally taken }\end{array}$ & Not stated & Northwest Cameroon & Focho et al., 2009a \\
\hline 20 & Insanity & Land F & $\begin{array}{c}\text { Decoction drunk } \\
\text { Wash patient }\end{array}$ & Not stated & Bulamogi, Uganda & Tabuti et al., 2003 \\
\hline 21 & Epilepsy & $\mathrm{L}$ & $\begin{array}{c}1 \mathrm{ml} \text { of juice from fresh leaf is } \\
\text { instilled, in every nostril in morning } \\
\text { time. }\end{array}$ & Mafouh & $\begin{array}{l}\text { Western Province, } \\
\text { Cameroon }\end{array}$ & $\begin{array}{l}\text { Noumi and Fozi, } \\
2003\end{array}$ \\
\hline 22 & Vaginal dryness & $\mathrm{B}$ & Herbal tea & Munyara & $\begin{array}{l}\text { Kibale National Park } \\
\text { area, Uganda }\end{array}$ & $\begin{array}{l}\text { Waisindye et al., } \\
\qquad 2016\end{array}$ \\
\hline 23 & Pregnancy care & $\mathrm{L}$ and $\mathrm{F}$ & Crush add water and bathe & Kifabakazi & $\begin{array}{l}\text { Mabira Central Forest } \\
\text { Reserve area, Uganda }\end{array}$ & Tugume et al., 2016 \\
\hline 24 & Facilitation of delivery & $\mathrm{B}$ & $\begin{array}{c}\text { Decoction is taken orally for } 60 \\
\text { days }\end{array}$ & Mefoufoueh & $\begin{array}{l}\text { Menoua division, } \\
\text { West Cameroon }\end{array}$ & Yemele et al., 2015 \\
\hline 25 & $\begin{array}{l}\text { Treat ailments of the } \\
\text { reproductive system }\end{array}$ & $\mathrm{L} / \mathrm{SB}$ & $\begin{array}{c}\text { Decoctions and concoctions are } \\
\text { orally taken }\end{array}$ & Not stated & Northwest Cameroon & Focho et al., 2009a \\
\hline 26 & $\begin{array}{l}\text { Heals dryness in } \\
\text { women, uterus (wounds } \\
\text { and swellings), }\end{array}$ & $\mathrm{R}, \mathrm{B}, \mathrm{F}, \mathrm{S}$ & Not stated & $\begin{array}{l}\text { Omunyara/ } \\
\text { Ekifabakazi }\end{array}$ & Western Uganda & $\begin{array}{l}\text { Musinguzi et al., } \\
2017\end{array}$ \\
\hline 27 & $\begin{array}{l}\text { Treating infertility in } \\
\text { female }\end{array}$ & SB & Not stated & Not stated & $\begin{array}{l}\text { Fako Division, } \\
\text { Cameroon }\end{array}$ & Fongod et al., 2013 \\
\hline 28 & Genital warts & $\mathrm{L}$ and $\mathrm{B}$ & $\begin{array}{l}\text { Decoction is taken along with salt } \\
\text { and applied on the affected area }\end{array}$ & Kifabakazi & $\begin{array}{l}\text { Wakiso District, } \\
\text { Uganda }\end{array}$ & Tugume et al., 2019b \\
\hline 29 & Hernia & B & $\begin{array}{l}\text { One glass of decoction is taken two } \\
\text { times a day for } 2 \text { months }\end{array}$ & Kifabakazi & Central Uganda & $\begin{array}{l}\text { Kibuuka and Anywar, } \\
2015\end{array}$ \\
\hline 30 & Venereal diseases & B & $\begin{array}{l}\text { Decoction along with the roots of } \\
\text { Rauwolfia vomitoria is used orally. }\end{array}$ & Not stated & $\begin{array}{l}\text { Lebialem highland, } \\
\text { Southwest Cameroon }\end{array}$ & Focho et al., 2009b \\
\hline \multirow[t]{2}{*}{31} & Tuberculosis & SB & Decoctions & Kifabakazi & Uganda & $\begin{array}{l}\text { Bunalema et al., } \\
\qquad 2014\end{array}$ \\
\hline & & SB & Decoctions & $\begin{array}{c}\text { Kinalisa/ Mwatashare/ } \\
\text { Kifabakazi }\end{array}$ & Uganda & Tabuti et al., 2010 \\
\hline 32 & $\begin{array}{l}\text { Treatment of Buruli } \\
\text { ulcer (infection caused } \\
\text { by Mycobacterium } \\
\text { ulcerans) }\end{array}$ & $\mathrm{R} / \mathrm{B}$ & $\begin{array}{l}\text { Paste is applied on ulcer and } \\
\text { infusion is used orally }\end{array}$ & $\begin{array}{c}\text { Biébiésrili / } \\
\text { Kwakuo ninsuo }\end{array}$ & Ghana & Fokou et al., 2015 \\
\hline 33 & Asthma & $\mathrm{L}$ & Not stated & Akoko & $\begin{array}{c}\text { Port Harcourt } \\
\text { Metropolis, Nigeria }\end{array}$ & $\begin{array}{l}\text { Nwauzoma and } \\
\text { Dappa , } 2013\end{array}$ \\
\hline 34 & $\begin{array}{l}\text { Child's respiratory } \\
\text { diseases }\end{array}$ & B & $\begin{array}{l}\text { Infusion is used by means of drip, } \\
\text { drink, or rectal washing, }\end{array}$ & Not stated & $\begin{array}{l}\text { Democratic Republic } \\
\text { of the Congo }\end{array}$ & $\begin{array}{l}\text { Disengomoka and } \\
\text { Delaveau et al., } 1983\end{array}$ \\
\hline 35 & Cough & B & Decoction & $\begin{array}{c}\text { Kifabakazi / } \\
\text { Shitsubi }\end{array}$ & Uganda & Anywar et al., 2020 \\
\hline \multirow[t]{3}{*}{36} & Common cold & $\mathrm{L}$ & $\begin{array}{c}\text { Decoction is taken half spoon trice } \\
\text { daily for } 3 \text { days }\end{array}$ & Kifabakazi & Uganda & $\begin{array}{l}\text { Walugembe et al., } \\
\qquad 2016\end{array}$ \\
\hline & & Sap & Infusion (internal) & Sebetaiyat & $\begin{array}{l}\text { South Nandi district } \\
\text { Kenya }\end{array}$ & $\begin{array}{l}\text { Ruth and Manani } \\
2010\end{array}$ \\
\hline & & Sap & Infusion & Sebetaiyat & Kenya & Jeruto et al., 2008 \\
\hline
\end{tabular}




\begin{tabular}{|c|c|c|c|c|c|c|}
\hline S.N. & Disease & $\begin{array}{l}\text { Plant } \\
\text { parts }\end{array}$ & Method of administration & Local name & Place & Ref. \\
\hline 37 & Sore throat & $\mathrm{L}$ & Not stated & Omutsurio & Kenya & Shiracko et al., 2016 \\
\hline \multirow[t]{3}{*}{38} & \multirow[t]{3}{*}{ Wound healing } & B & Not stated & Not stated & $\begin{array}{l}\text { Naogaon District, } \\
\text { Bangladesh }\end{array}$ & $\begin{array}{c}\text { Kona and Rahman, } \\
2016\end{array}$ \\
\hline & & SB & Paste & Not stated & Ghana & Agyare et al., 2016 \\
\hline & & B & Bark-sap & Not stated & $\begin{array}{l}\text { Democratic Republic } \\
\text { of the Congo }\end{array}$ & $\begin{array}{l}\text { Terashima and } \\
\text { Malasi, } 1991\end{array}$ \\
\hline 39 & Swollen cheeks & $\mathrm{L} / \mathrm{SB}$ & $\begin{array}{l}\text { Sore is cleaned with decoction } \\
\text { using a cotton wool }\end{array}$ & $\begin{array}{l}\text { Biébiésrili / } \\
\text { Kwakuo ninsuo }\end{array}$ & Ghana & Fokou et al., 2015 \\
\hline \multirow[t]{2}{*}{40} & \multirow[t]{2}{*}{ Haemorrhoids } & $\mathrm{L} / \mathrm{SB}$ & $\begin{array}{l}\text { Decoctions and concoctions applied } \\
\text { topically }\end{array}$ & Not stated & Northwest Cameroon & Focho et al., 2009a \\
\hline & & L, SB & Decoction & Kuokuonesuo & $\begin{array}{l}\text { Bosomtwi-Atwima- } \\
\text { Kwanwoma, Ghana }\end{array}$ & Agyare et al., 2009 \\
\hline \multirow[t]{5}{*}{41} & \multirow[t]{5}{*}{ Skin infection } & $\mathrm{L}$ & Extract with jelly smeared on skin & Not stated & $\begin{array}{l}\text { Buikwe district, } \\
\text { Uganda }\end{array}$ & Shehu et al., 2018 \\
\hline & & $\mathrm{B} / \mathrm{L}$ & Infusion & $\begin{array}{l}\text { Ucche kayi } \\
\text { mara }\end{array}$ & Karnataka, India & $\begin{array}{l}\text { Prashanth Kumar } \\
\quad \text { et al., } 2016\end{array}$ \\
\hline & & B & Bark & Rugtoora & Uttar Pradesh, India & Shukla et al., 2014 \\
\hline & & $\mathrm{L}$ & Not stated & Turi & Odisha, India & $\begin{array}{l}\text { Kumar and Dash , } \\
2012\end{array}$ \\
\hline & & $\mathrm{R} / \mathrm{B}$ & $\begin{array}{l}\text { Sore is cleaned with decoction } \\
\text { using a cotton wool and paste of the } \\
\text { bark is used to bandage ulcer. }\end{array}$ & $\begin{array}{c}\text { Biébiésrili / } \\
\text { Kwakuo ninsuo }\end{array}$ & Ghana & Fokou et al., 2015 \\
\hline \multirow[t]{5}{*}{42} & \multirow[t]{5}{*}{ Skin rashes } & $\mathrm{R}, \mathrm{B}, \mathrm{F}, \mathrm{S}$ & Not stated & Omunyara/ Ekifabakazi & Western Uganda & $\begin{array}{l}\text { Musinguzi et al., } \\
2017\end{array}$ \\
\hline & & $\mathrm{L}, \mathrm{SB}$ & Decoction & Kuokuonesuo & $\begin{array}{l}\text { Bosomtwi-Atwima- } \\
\text { Kwanwoma, Ghana }\end{array}$ & Agyare et al., 2009 \\
\hline & & $\mathrm{L}$ and $\mathrm{SB}$ & $\begin{array}{l}\text { Decoction is taken along with salt } \\
\text { and applied on the affected area }\end{array}$ & Kifabakazi & $\begin{array}{l}\text { Wakiso District, } \\
\text { Uganda }\end{array}$ & Tugume et al., 2019b \\
\hline & & $\mathrm{L} / \mathrm{B}$ & $\begin{array}{l}\text { Decoction/infusion applied } \\
\text { topically }\end{array}$ & Not stated & Western Kenya & Omale et al., 2020 \\
\hline & & $\mathrm{L}$ & $\begin{array}{l}\text { Sore is cleaned with decoction } \\
\text { using a cotton wool and paste of } \\
\text { bark is used to bandage the ulcer }\end{array}$ & Kwakuo ninsuo & Ghana & Henry et al., 2013 \\
\hline 43 & Chicken-pox & $\mathrm{B}$ & $\begin{array}{l}\text { Decoction mix from bark of } S \text {. } \\
\text { campanulata and } P \text {. hylodendron } \\
\text { and ground stalk of } C \text {. afer is used } \\
\text { for bathing two times daily for } 15 \\
\text { days. purging is done by } 250 \mathrm{ml} \text { of } \\
\text { decoction }\end{array}$ & $\begin{array}{l}\text { Evouvou / } \\
\text { Ebolowa }\end{array}$ & Cameroon & Ngane et al., 2011 \\
\hline 44 & Genital herpes & B & $\begin{array}{l}\text { Bathing with a decoction of bark of } \\
\text { S. campanulata and } \\
\text { ground stalk of } C \text {. afer }\end{array}$ & $\begin{array}{l}\text { Evouvou / } \\
\text { Ebolowa }\end{array}$ & Cameroon & Ngane et al., 2011 \\
\hline 45 & Measles & $\mathrm{L}$ & Decoction & Oruru & Western Nigeria & $\begin{array}{c}\text { Oladunmoye et al., } \\
2011\end{array}$ \\
\hline 46 & HIV/AIDS & $\begin{array}{l}\mathrm{SB}, \mathrm{L}, \\
\mathrm{RB}\end{array}$ & Decoction & Kifabakazi & $\begin{array}{l}\text { Mpigi District, } \\
\text { Uganda }\end{array}$ & $\begin{array}{c}\text { Nyamukuru et al., } \\
2017\end{array}$ \\
\hline 47 & Tongue infections & $\mathrm{L}$ & Crushed, oral & Omutirisya & $\begin{array}{l}\text { Kakamega County, } \\
\text { Western Kenya }\end{array}$ & Odongo et al., 2018 \\
\hline 48 & Chronic leg ulcer & SB & $\begin{array}{l}\text { Decoction is taken orally and } \\
\text { applied topically }\end{array}$ & Imi ewu & South eastern Nigeria & Nwafor et al., 2018 \\
\hline
\end{tabular}




\begin{tabular}{|c|c|c|c|c|c|c|}
\hline S.N. & Disease & $\begin{array}{l}\text { Plant } \\
\text { parts }\end{array}$ & Method of administration & Local name & Place & Ref. \\
\hline 49 & $\begin{array}{l}\text { Stomach, skin and } \\
\text { throat cancer }\end{array}$ & $\mathrm{B}, \mathrm{L}$ & Decoction oral & Not stated & Ghana & Agyare et al., 2018 \\
\hline 50 & Fibromyoma & SB & Infusion & Evovon & South Cameroon & Noumi, 2010 \\
\hline 51 & $\begin{array}{l}\text { Antidote against animal } \\
\text { poisons }\end{array}$ & F, SB, L & Not stated & Not stated & India & Santosh et al., 2019 \\
\hline 52 & Dog bite & B & $\begin{array}{l}\text { Crushed bark is applied on the } \\
\text { wound and } 500 \mathrm{ml} \text { of decoction is } \\
\text { taken orally }\end{array}$ & Baganda & Southern Uganda & Hamill et al., 2003 \\
\hline
\end{tabular}

AP-Aerial Part; B-Bark; SB-Stem bark; F-Flowers; L-Leaf; R-Root; S-Stem.

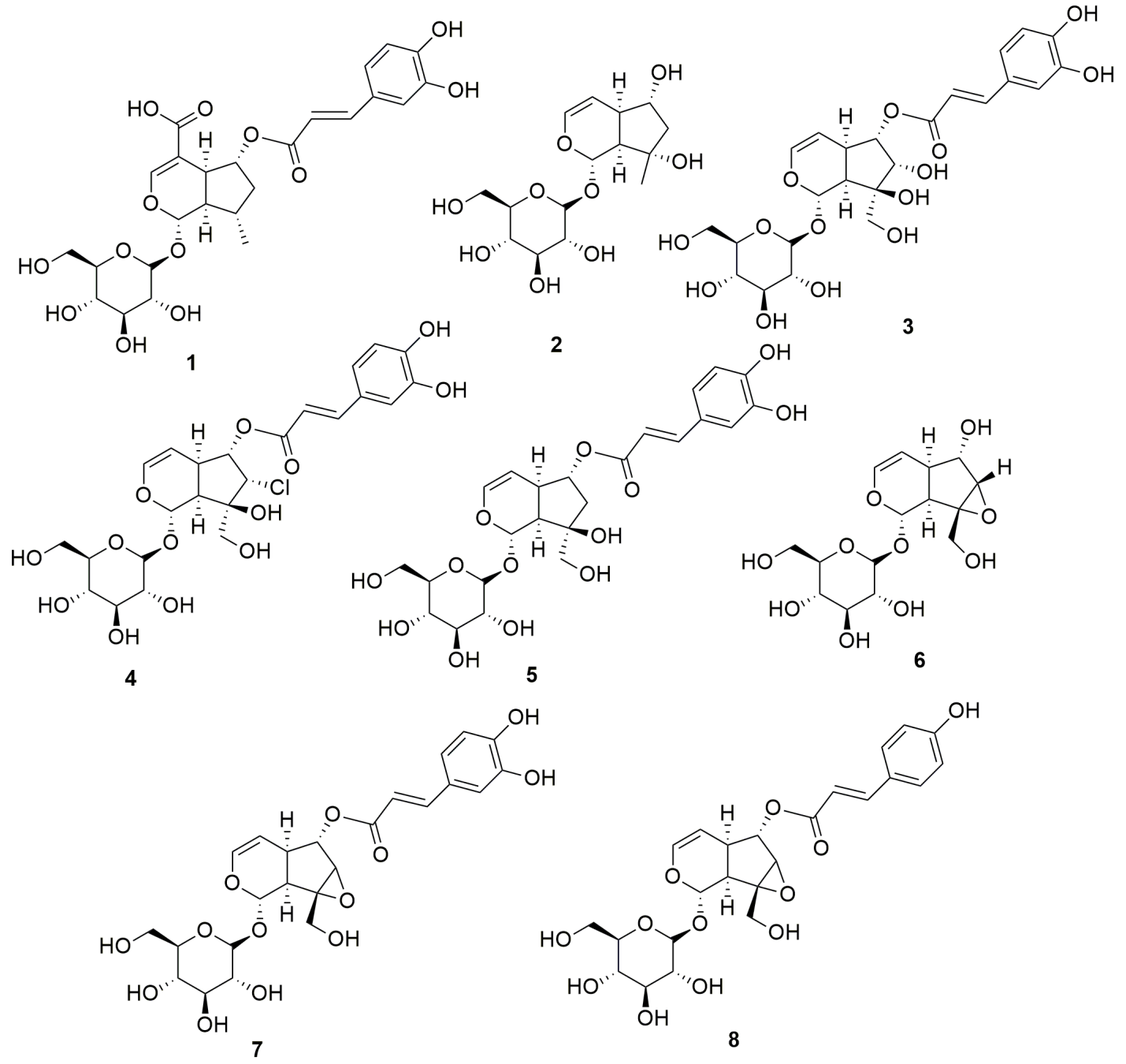

Figure 1. Iridoids isolated from Spathodea campanulata.

found in S. campanulata. Iridoids are a kind of monoterpenoids containing cyclopenta[c]pyranoid ring system. They are typically found as glycosides, which are associated with glucose molecules. In 1991, the first iridoid glycoside isolated from stem bark was verminoside (7) (Niyonzima et al., 1991). Later, five more iridoid glycosides (1-6) were isolated from the leaves (Gouda, 2009a). Specioside (8) has been detected in the flower of the plant (Elusiyan et al., 2011). Phytochemical analysis of leaves and stem bark (Ngouela et al., 1988, 1990, 1991) revealed the presence of different triterpenoids, viz. spathodic acid (9), 


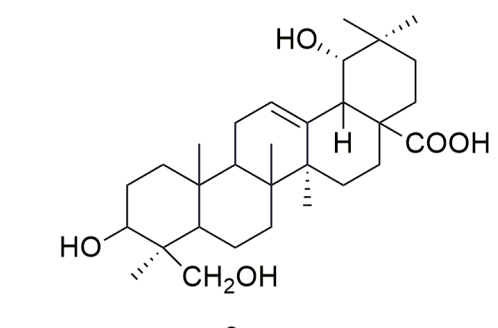<smiles>CC(=O)OC1CCC2(C)C(CC[C@@]34C[C@]5(CCC6(C(=O)O)CCC(C)(C)CC6C5=CCC23)C4C)C1(C)C</smiles>

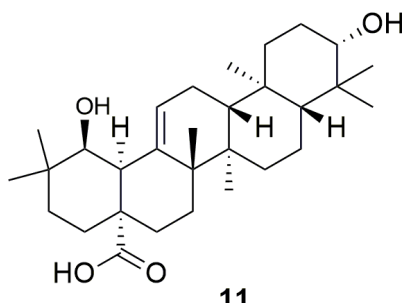

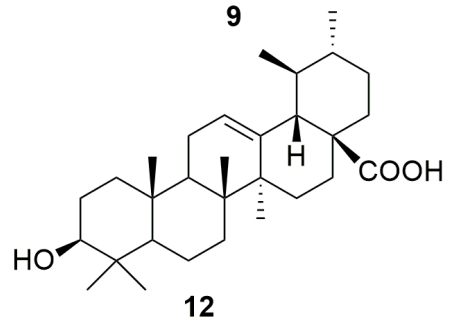

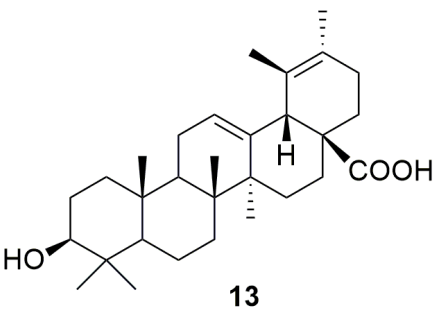

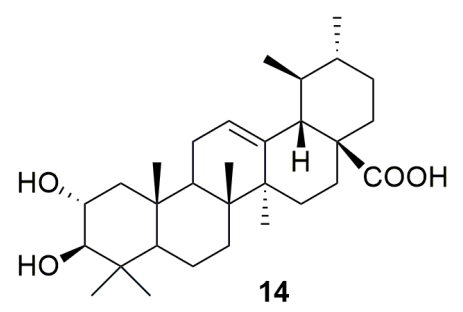

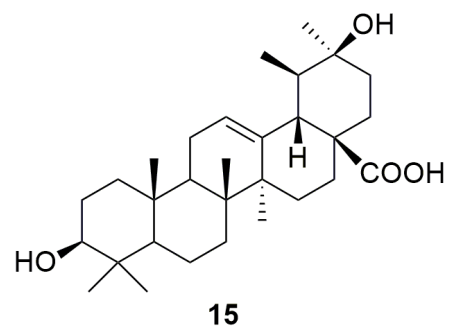

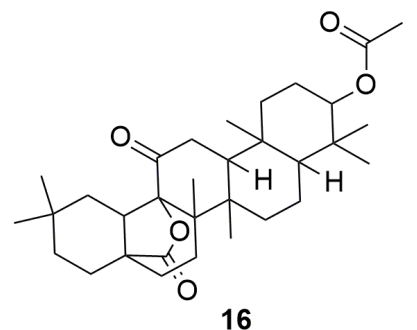<smiles>CC1(C)CCC2(C(=O)O)CCC3C4=CCC5C6(C)CCC(O)C(C)(C)C6CCC45C3CCC2(C)C1</smiles>

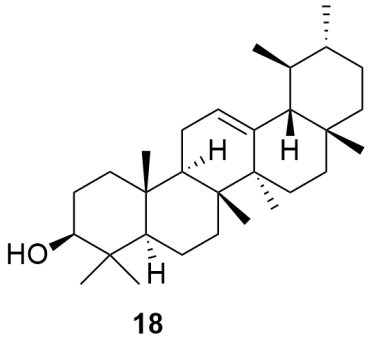

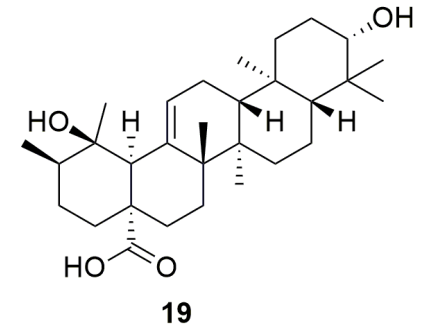

17

Figure 2. Triterpenoids isolated from Spathodea campanulata.

$3 \beta$-acetoxyoleanolic acid (10), siaresinolic acid (11), $3 \beta$-acetoxy12-hydroxyoleanan-28,13-olide, and oleanolic acid (16). Various other triterpenoids, such as ursolic acid (12), tomentosolic acid (13), 33,20ß-Dihydroxyurs-12-en-28-oic acid (15) (Amusan et al., 1996), $\alpha$-amyrin (18) (Nazif, 2007), pomolic acid (19) (Mbosso et al., 2008), urs-12-en-27 $\alpha$, and 30 dioic acid 3-O- $\alpha-$ L-rhamnopyranosyl $(\mathbf{1} \rightarrow \mathbf{2}) \alpha$-L-arabinopyranoside (20) (Ilodigwe et al., 2010b), were identified from the bark and aerial parts. Several sterols, such as spathodol (21), $\beta$-sitosterol-3-O- $\beta$-Dglucopyranoside (22) (Ngouela et al., 1991), $\beta$-sitosterol-3acetate (23) (Shehab et al., 2014), stigmasterol (24), cholesterol (25), and campesterol (26) (Nazif, 2007), have been detected from various parts of the plant. Regarding phenolic compounds, several researchers reported the presence of a range of flavonoids or anthocyanins (36-60) (Table 3) in the flower, stem bark, leaf, and aerial parts of the plant. Other groups of compounds found in $S$. campanulata include cinnamic acid derivatives (27-33), cerebrosides $(\mathbf{3 4 , 3 5})$, carotenoids $(\mathbf{6 1}-\mathbf{7 1})$, monoterpenoids $(\mathbf{6 8}-$ 74) and sesquiterpenoids (75-84), diterpenoids (abietatriene) (85), coumarins $(\mathbf{8 6 , 8 7})$, aromatic acid, and their esters (88-95).
Recently, a new cerebroside campanulatoside was isolated from the stem bark of S. campanulate (Magnibou et al., 2021). The phytochemicals possessing biological activities are listed in Table 4.

\section{PHARMACOLOGICAL ACTIVITY}

\section{Antimalarial activity}

In observation of the significance of this plant in treating malaria by the traditional healer, systematic examinations have been carried for antimalarial action by Makinde and group. The schizontocidal activity of leaf extracts was evaluated against Plasmodium berghei in mice. The Extracts were tested in both early and established infections and proved to be more efficient in curing early infection. The aqueous leaf extract (ALE) exhibited highest antiplasmodial action at a concentration of $400 \mathrm{mg} / \mathrm{kg} /$ day and percentage of chemosuppression was $73.8 \%$. The effective dose for $50 \%$ of the population was found to be around 100-400 $\mathrm{mg} / \mathrm{kg} /$ day. Furthermore, the chromatographic fractions of the chloroform leaf extract (CLE) produced $61.0 \%$ chemosuppression 


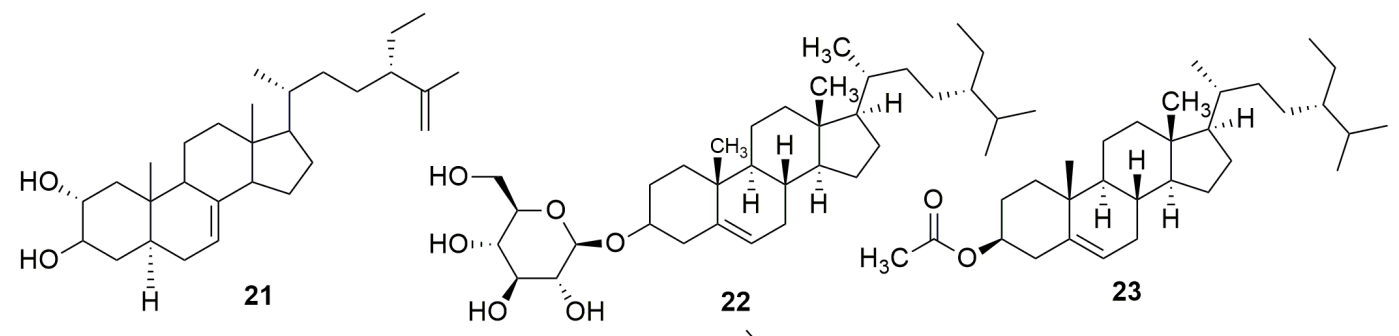

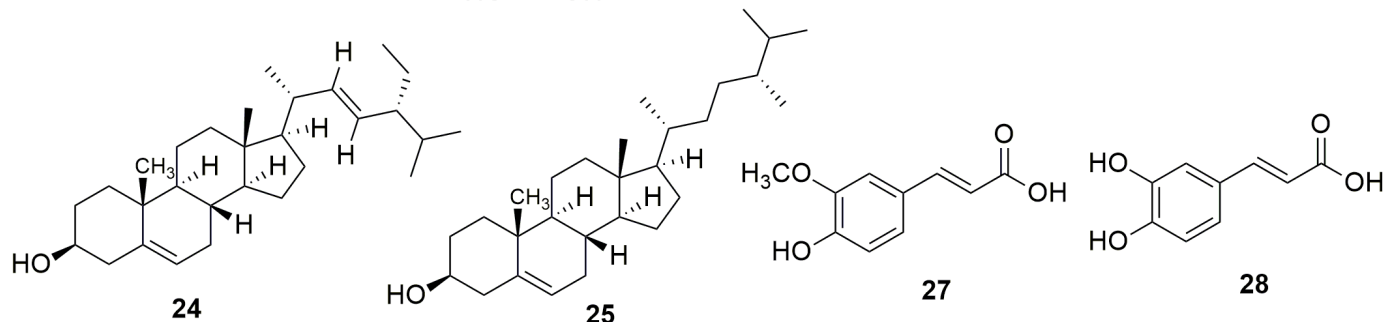<smiles>O=C(O)/C=C/c1ccc(O)cc1</smiles>

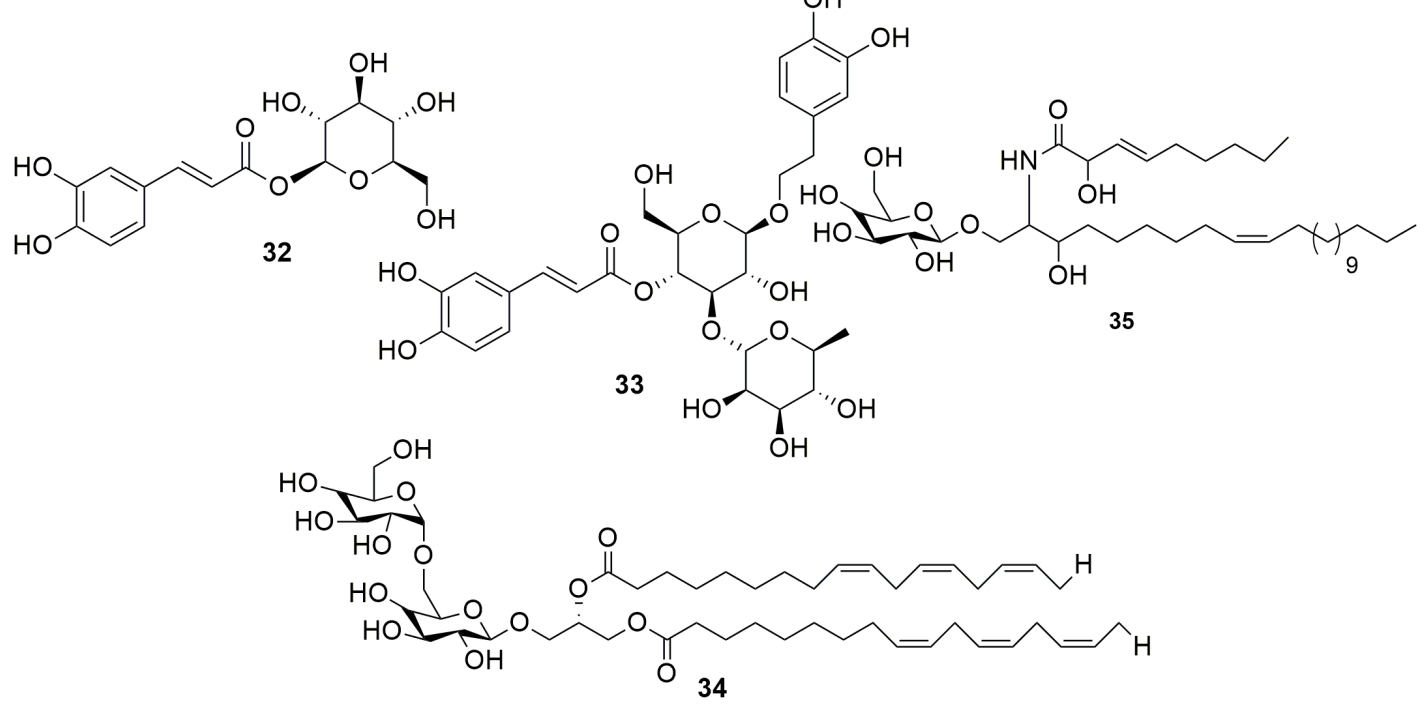

Figure 3. Sterols, cinnamic acid derivatives and Cerebrosides isolated from Spathodea campanulata.

at $40 \mathrm{mg} / \mathrm{kg} /$ day. The extracts were found to be less effective than chloroquine, which produced $99.3 \%$ suppression at the 20 $\mathrm{mg} / \mathrm{kg} /$ day dose (9) (Makinde et al., 1987). The chloroform stem bark extract (CBE) and hexane stem bark extract (HBE) of $S$. campanulata were evaluated for blood schizontocidal activity by Rane and 4-day tests. Both extracts showed significant activities. The HBE suppressed $22 \%-80 \%$ of infections at the $50-400 \mathrm{mg} / \mathrm{kg} /$ day dose in the 4-day test with a mean survival time period of 18.0 and 13.0 days. The CBE also demonstrated significant activity at $100-400 \mathrm{mg} / \mathrm{kg} /$ day. Percentage suppression was in between $52 \%$ and $74 \%$. The schizontocidal action of CBE was confirmed by measuring the mean survival time in mice, which was found to be 15.2 and 19.2 days. The CBE and HBE clearly demonstrated antimalarial action not only by suppressing parasitaemia but also by prolonging the lifetime of the mice (Makinde et al., 1988). The activity of the different fractions of CBE was evaluated by Fink and Kretschmar's and Rane's tests. Few of the chromatographic fractions exerted significant antimalarial action than the crude extracts. One of the fractions was mainly active at $40 \mathrm{mg} / \mathrm{kg} /$ day. $82 \%$ of the infection was suppressed with a mean survival time of 19.2 days (Makinde et al., 1990). The chemical entities revealed to be responsible for antimalarial activities were ursolic acid (6), tomentosolic acid (7), and 3 $\beta, 20 \beta$-dihydroxyurs-12-en-28 oic acid (9). The isolated compounds suppressed parasitaemia in a 


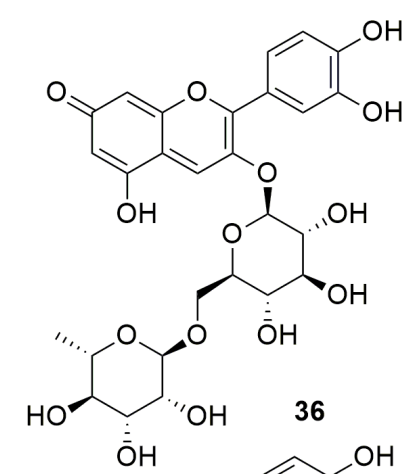<smiles>CC1OC(OCC2OC(Oc3cc4c(O)cc(O)cc4[o+]c3-c3ccc(O)cc3)C(O)C(O)C2O)C(O)C(O)C1O</smiles><smiles>Oc1cc(O)c2c(c1)O[C@H](c1ccc(O)c(O)c1)[C@H](O)C2</smiles>

38<smiles>O=c1c(O)c(-c2ccc(O)c(O)c2)oc2cc(O)cc(O)c12</smiles>

40<smiles>CCC1CC(O)C(O)C(Oc2c(-c3ccc(O)cc3)oc3c(OC)c(O)cc(O)c3c2=O)O1</smiles>

$\mathrm{OH}$ ŌH<smiles>[13CH3]c1ccc(-c2oc3cc(O)cc(O)c3c(=O)c2O[C@@H]2O[C@H](CO)[C@@H](O)[C@H](O)[C@H]2O[C@@H]2O[C@H](CO)[C@@H](O)[C@H](O)[C@H]2O)cc1</smiles>

46<smiles>COc1c(-c2ccc(O)c(O)c2)oc2cc(O)cc(O)c2c1=O</smiles>

41<smiles>O=c1c(O[C@@H]2O[C@H](CO)[C@@H](O)[C@H](O)[C@H]2O)c(-c2ccc(O)cc2)oc2cc(O)cc(O)c12</smiles><smiles>C[C@H]1O[C@H](OC[C@H]2O[C@H](Oc3c(-c4ccc(O)cc4)oc4cc(O)cc(O)c4c3=O)[C@H](O)[C@H](O)[C@H]2O)[C@H](O)[C@@H](O)[C@H]1O</smiles><smiles>C[C@H]1O[C@H](OC[C@H]2O[C@H](Oc3c(-c4ccc(O)cc4)oc4cc(O)cc(O)c4c3=O)[C@H](O)[C@H](O)[C@H]2O)[C@H](O)[C@@H](O)[C@H]1O</smiles>

48<smiles>C[C@@H]1C[C@H](Oc2cc3oc(-c4ccc(O)cc4)c(O)c(=O)c3c(O)c2O)[C@H](O)[C@@H](O)[C@@H]1O</smiles>

51<smiles>O=CO[C@@H]1[C@H](O)C[C@@H](CO)O[C@@H]1Oc1cc(O)c2c(c1)O[C@H](c1ccc(O)cc1)[C@@H](O)C2=O</smiles>

49<smiles>O=c1cc(-c2ccc(O)cc2)oc2cc(O)cc(O)c12</smiles>

52<smiles>O=c1c(O[C@@H]2O[C@H](CO)[C@@H](O)[C@H](O)[C@H]2O[C@H]2OC[C@@H](O)[C@H](O)[C@H]2O)c(-c2ccc(O)c(O)c2)oc2cc(O)cc(O)c12</smiles>

50<smiles>O=c1cc(-c2ccc(O)c(O)c2)oc2cc(O)cc(O)c12</smiles>

53

Figure 4. Flavonoides isolated from Spathodea campanulata. 


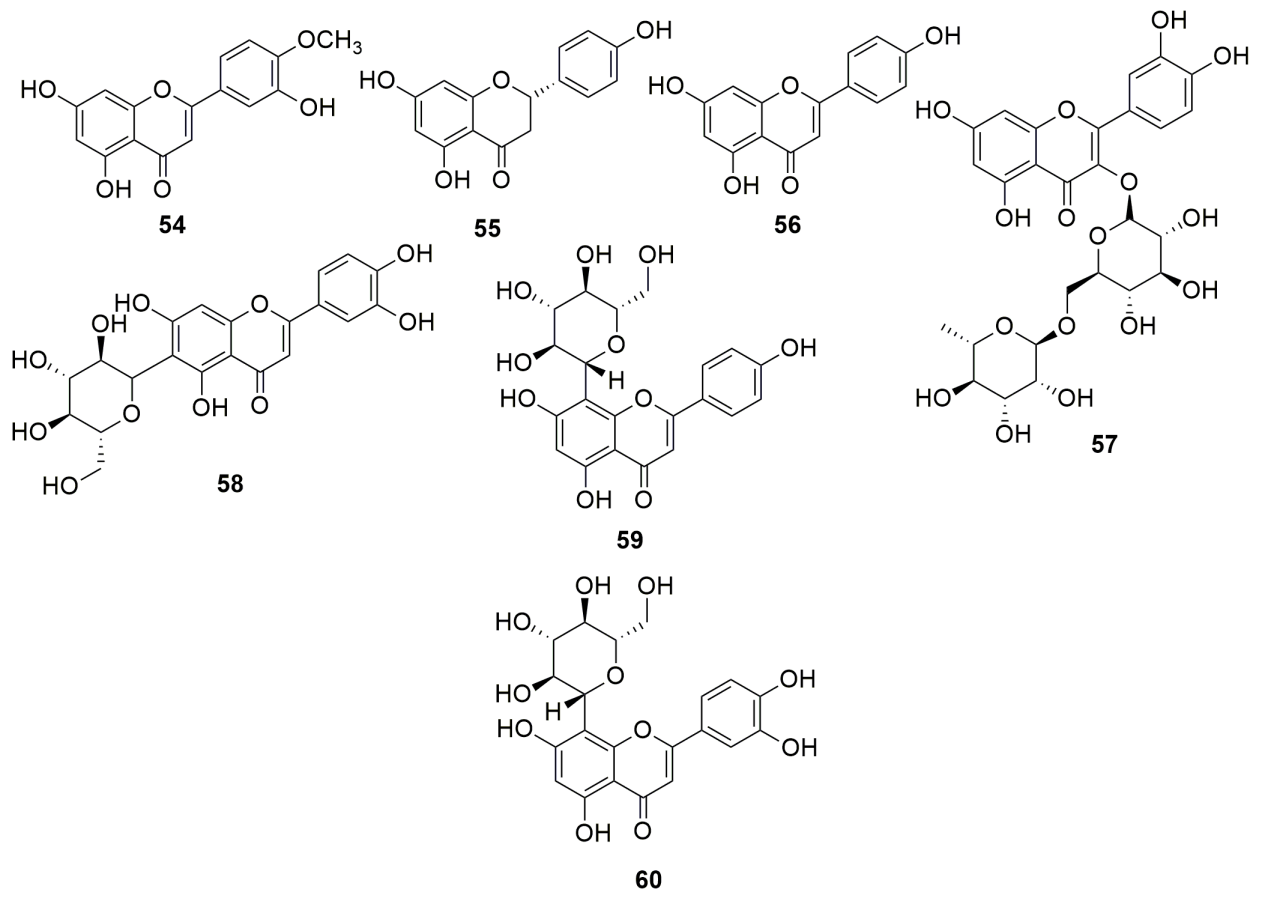

Figure 5. Flavonoides isolated from Spathodea campanulata.

dose-dependent manner and exhibited high mean survival times. Among the isolated compounds, ursolic acid (6) was highly active. At a dose of $60 \mathrm{mg} / \mathrm{kg} /$ day, it suppressed $97 \%$ of parasitaemia with a mean survival period of 25 days. The action was comparable to the chloroquine at a dose of $10 \mathrm{mg} / \mathrm{kg} /$ day. The triterpenoid ursolic acid was found to be non-toxic when fed to guinea pigs, rats, rabbits, and chickens at dose levels of 1,000-5,000 mg/kg/ day body weight. It was also not toxic to humans at a dose of $20 \mathrm{mg} / \mathrm{kg} /$ day (Amusan et al., 1996). The in vitro antimalarial activity of ethanolic bark extract (EBE) and fractions was carried out by employing chloroquine-sensitive and resistant Plasmodium falciparum by schizont maturation inhibition assay. EBE (both $50 \%$ and $80 \%$ ) did not show significant activity. Half-maximal inhibitory concentration value of $50 \%$ EBE was observed at 88.3 (chloroquine sensitive) and $108.2 \mu \mathrm{g} / \mathrm{ml}$ (chloroquine resistant) against $P$. falciparum strain. Accordingly, EBE (80\%) exhibited $\mathrm{IC}_{50}$ values of 68.5 and $100 \mu \mathrm{g} / \mathrm{ml}$ (Dhanabalan et al., 2008). The ethyl acetate bark extract of $S$. campanulata displayed $28.9 \%$ inhibition of $P$. falciparum $\mathrm{FcB} 1$ at $10 \mu \mathrm{g} / \mathrm{ml}$ (Lacroix et al., 2011).

From the above-mentioned studies it may be concluded that most of the experiments were conducted by employing stem bark extracts. The chloroform bark extract showed better activity when compared to others. The toxicity reports indicated safety of the isolated ursolic acid. However, the high dose requirement of $60 \mathrm{mg} /$ $\mathrm{kg} /$ day for pronounced activity compared to chloroquine $(10 \mathrm{mg} / \mathrm{kg}$ / day) in the studies is a matter of concern. Furthermore, there is a scope to study the roots and seeds for analogous activities and isolation of compounds with convincingly superior biological activity.

\section{Antidiabetic activity}

The stem bark decoction (SBD) of $S$. campanulata $(8$ $\mathrm{g}$ bark powder $/ \mathrm{kg} \mathrm{bw}$ ) was tested for antidiabetic effect in the streptozocin (STZ)-induced diabetic mice model. It showed a hypoglycemic effect but did not influence insulin levels (Niyonzima et al., 1990). SBD also decreased blood glucose amount during the oral glucose tolerance test (OGTT) in normal mice. The water and butanol fractions obtained from bark decoction also showed hypoglycemic activity but did not influence insulin levels in STZ diabetic mice (Niyonzima et al., 1993). Different fractions of the SBD separated by column chromatography were evaluated for their hypoglycemic effect. The most polar fraction composed mainly of polysaccharides, which considerably decreased the blood glucose levels after 30, 60, and 90 minutes of glucose load. However, few of the fractions showed a significant hyperglycemic effect toward the end of the experiment (Niyonzima et al., 1999). Aqueous methanolic stem bark extract significantly decreased blood glucose levels after 2 hour at a dose of $800 \mathrm{mg} / \mathrm{kg}$ in normoglycemic rats. In OGTT, the extract reduced glycemia $(63 \%)$ at the $400 \mathrm{mg} / \mathrm{kg}$ dose. It also reduced glycemia (29\%) in alloxan-induced diabetes mellitus rats with the $400 \mathrm{mg} / \mathrm{kg}$ dose in the acute phase. The multiple dose treatment with the extract led to the decrease in alloxan-induced hyperglycemia at the end of the 18th day (Tanayen et al., 2014). The methanolic extracts of the flowering branch and bark were screened for their antidiabetic activity in mice at a dose of $500 \mathrm{mg} / \mathrm{kg}$ bw. Blood insulin, glucose, cholesterol, and triacylglycerol levels and the concentration of insulin receptors in muscle tissue were estimated at the end of the treatment. The bark extract resulted in the significant reduction in blood glucose $(44.5 \%$ decline) after 1 hour of treatment. A significant rise in insulin receptors level ( $28 \%$ increment) was also observed for bark extract. The study concluded that the bark extract modified the tissue expression of insulin receptors (Abdraboh and Ahmed, 2015). The solvent fractions of methanolic bark extract (MBE) were separately tested for antidiabetic activity using 
OGTT. All fractions demonstrated reductions in hyperglycemia. The residual aqueous fraction reduced hyperglycemia up to $74.7 \%$ at the $200 \mathrm{mg} / \mathrm{kg}$ dose (Kihdze et al., 2016). The ethanolic flower extract (EFE) of $S$. campanulata also exerted significant anti-hyperglycemic activity in alloxan-induced diabetic mice at a dose of $500 \mathrm{mg} / \mathrm{kg}$. The activity was correlated to its phenolic components (Shehab et al., 2014).

From the above discussion, it can be concluded that aqueous and alcoholic extracts obtained from bark and flower of $S$. campanulata at high doses (400-800 mg/kg) showed significant anti-hyperglycemic activity. The antidiabetic activity was mainly attributed to the most polar fraction composed mainly of polysaccharides. The underlined mechanism of action for antidiabetic activity is due to expression of insulin receptor. With this information on the hypoglycemic prospective, there is scope by thoroughly studying and using different parts of the plant against a variety of models available for diabetes.

\section{Wound healing activity}

Traditionally, the stem bark of $S$. campanulata is considered as an effective remedy to heal wound. The researcher determined the wound healing activity of the MBE

Table 3. Phytochemicals isolated from S. campanulate.

\begin{tabular}{|c|c|c|c|}
\hline S.N. & Name & Plant part & Reference \\
\hline & Iridoids & & \\
\hline \multirow[t]{2}{*}{1} & 6'-O-trans-caffeoyl-loganic acid & $\mathrm{L}$ & Gouda, 2009a \\
\hline & & $\mathrm{RP}$ & Pianaro et al., 2007 \\
\hline \multirow[t]{2}{*}{2} & Ajugol & $\mathrm{L}$ & Gouda, 2009a \\
\hline & & SB and $\mathrm{F}$ & Elusiyan et al., 2011 \\
\hline 3 & 6-O-trans-caffeoyldecinnamoyl Globularimin (Spatheoside A) & $\mathrm{L}$ & Gouda, 2009a \\
\hline 4 & 6-O-trans-caffeoyl-asystasioside E (Spatheoside B) & $\mathrm{L}$ & Gouda, 2009a \\
\hline 5 & 6-O-trans-caffeoyl-5,7-bisdeoxycynanchoside (Spatheoside C) & $\mathrm{L}$ & Gouda, 2009a \\
\hline 6 & Catalpol & $\mathrm{L}$ & Gouda, 2009a \\
\hline \multirow{3}{*}{7} & & SB & Niyonzima et al., 1991 \\
\hline & 6-O-caffeoylcatalpol (Verminoside) & $\mathrm{L}$ & Gouda, 2009a \\
\hline & & $\mathrm{L}, \mathrm{SB}$ and $\mathrm{F}$ & Elusiyan et al., 2011 \\
\hline \multirow{3}{*}{8} & & $\mathrm{~L}$ & Boniface et al., 2014 \\
\hline & Specioside & $\mathrm{F}$ & Elusiyan et al., 2011 \\
\hline & Triterpenoids & & \\
\hline \multirow{2}{*}{9} & \multirow{2}{*}{ Spathodic acid } & $\mathrm{SB}$ & Ngouela et al., 1990 \\
\hline & & SB & Ngnameko et al., 2020 \\
\hline \multirow{2}{*}{10} & \multirow{2}{*}{$3 \beta$-acetoxyoleanolic acid } & SB & Ngouela et al., 1988 \\
\hline & & $\mathrm{L}$ & Ngouela et al., 1991 \\
\hline \multirow{2}{*}{11} & \multirow[t]{2}{*}{ Siaresinolic acid } & SB & Ngouela et al., 1988 \\
\hline & & $\mathrm{L}$ & Ngouela et al., 1991 \\
\hline \multirow{2}{*}{12} & 38-bydroyvurs-12 en-28_oic acid (Utrolic acid) & SB & Amusan et al., 1996 \\
\hline & 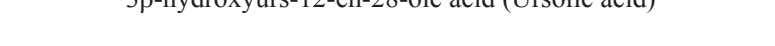 & SB & Ngnameko et al., 2020 \\
\hline \multirow{2}{*}{13} & \multirow{2}{*}{ 3ß-hydroxyurs-12,19-dien-28-oic acid (Tomentosolic acid) } & SB & Amusan et al., 1996 \\
\hline & & SB & Ngnameko et al., 2020 \\
\hline 14 & Corosolic Acid & SB & Ngnameko et al., 2020 \\
\hline 15 & $3 \beta, 20 \beta$-Dihydroxyurs-12-en-28-oic acid (20ß-hydroxyursolic acid) & SB & Amusan et al., 1996 \\
\hline \multirow{2}{*}{16} & $3 \beta$-acetoxy-12-hydroxyoleanan-28,13-olide & SB & Ngouela et al., 1988 \\
\hline & & $\mathrm{L}$ & Ngouela et al., 1991 \\
\hline \multirow{3}{*}{17} & Oleanolic acid & SB & Ngouela et al., 1988 \\
\hline & & $\mathrm{L}$ & Ngouela et al., 1991 \\
\hline & & SB & Mbosso et al., 2008 \\
\hline 18 & $\alpha$-amyrin & $\mathrm{AP}$ & Nazif, 2007 \\
\hline
\end{tabular}




\begin{tabular}{|c|c|c|c|}
\hline S.N. & Name & Plant part & Reference \\
\hline 19 & Pomolic acid & SB & Mbosso et al., 2008 \\
\hline \multirow[t]{2}{*}{20} & $\begin{array}{l}\text { Urs-12-en-27 } \alpha, 30 \text { dioic acid 3-O- } \alpha \text {-L-rhamnopyranosyl }(1 \rightarrow 2) \alpha \text {-L- } \\
\text { arabinopyranoside }\end{array}$ & $\mathrm{L}$ & Ilodigwe et al., 2010b \\
\hline & Sterols & & \\
\hline \multirow{3}{*}{21} & \multirow{3}{*}{ Spathodol } & $\mathrm{L}$ & Ngouela et al., 1991 \\
\hline & & SB & Ngnameko et al., 2020 \\
\hline & & SB & Ngouela et al., 1990 \\
\hline \multirow[t]{2}{*}{22} & $\beta$-sitosterol-3-O- $\beta$-D-glucopyranoside & $\mathrm{L}$ & Ngouela et al., 1991 \\
\hline & & SB & Mbosso et al., 2008 \\
\hline 23 & $\beta$-sitosterol-3-acetate & $\mathrm{F}$ & Shehab et al., 2014 \\
\hline 24 & Stigmasterol & $\mathrm{AP}$ & Nazif, 2007 \\
\hline 25 & Campesterol & $\mathrm{AP}$ & Nazif, 2007 \\
\hline \multirow[t]{2}{*}{26} & Cholesterol & $\mathrm{AP}$ & Nazif, 2007 \\
\hline & Cinnamic acid derivatives & & \\
\hline \multirow{6}{*}{27} & \multirow{4}{*}{ Ferulic acids } & SB & Ngouela et al., 1991 \\
\hline & & $\mathrm{AP}$ & Nazif, 2007 \\
\hline & & Land F & Santos et al., 2020 \\
\hline & & $\mathrm{F}$ & Shehab et al., 2014 \\
\hline & & $\mathrm{AP}$ & Nazif, 2007 \\
\hline & & Land F & Elusiyan et al., 2011 \\
\hline \multirow[t]{3}{*}{28} & Caffeic acid & $\mathrm{L}$ & Subramanian et al., 1973 \\
\hline & & $\mathrm{L}, \mathrm{F}$ and $\mathrm{N}$ & Santos et al., 2020 \\
\hline & & $\mathrm{F}$ & Shehab et al., 2014 \\
\hline 29 & p-Coumaric acid & $\mathrm{F}$ & Santos et al., 2020 \\
\hline 30 & 1-O-(E)-caffeoyl- $\beta$-gentiobiose & $\mathrm{L}$ & Boniface et al., 2014, 2015 \\
\hline \multirow{2}{*}{31} & \multirow{2}{*}{ Chlorogenic acid } & $\mathrm{F}$ & Santos et al., 2020 \\
\hline & & $\mathrm{F}$ & Shehab et al., 2014 \\
\hline 32 & 1-O-caffeoyl- $\beta$-D-glucopyranoside & $\mathrm{L}$ & Gouda, 2009b \\
\hline \multirow[t]{2}{*}{33} & Acteoside & $\mathrm{L}$ & Gouda, 2009b \\
\hline & Cerebrosides & & \\
\hline 34 & 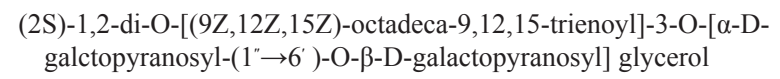 & $\mathrm{L}$ & Boniface et al., 2014 \\
\hline \multirow[t]{2}{*}{35} & Spathoside & SB & Mbosso et al., 2008 \\
\hline & Flavonoids & & \\
\hline 36 & Cyanidin-3-O-rutinoside & $\mathrm{F}$ & Scogin, 1980 \\
\hline 37 & Pelargonidin-3-rutinoside & $\mathrm{F}$ & Scogin, 1980 \\
\hline 38 & Catechin & $\mathrm{F}$ & Shehab et al., 2014 \\
\hline \multirow[t]{2}{*}{39} & Catechin-3-O- $\alpha$-rhamnopyranoside & $\mathrm{F}$ & Shehab et al., 2014 \\
\hline & & $\mathrm{F}$ & Subramanian et al., 1972 \\
\hline \multirow[t]{2}{*}{40} & Quercetin & $\mathrm{F}$ & Shehab et al., 2014 \\
\hline & & $\mathrm{B}$ & Ngnameko et al., 2020 \\
\hline 41 & Quercetin 3-methyl ether & AP & Nazif, 2007 \\
\hline \multirow{2}{*}{42} & \multirow{2}{*}{ Kaempferol } & $\mathrm{F}$ & Shehab et al., 2014 \\
\hline & & $\mathrm{B}$ & Ngnameko et al., 2020 \\
\hline
\end{tabular}




\begin{tabular}{|c|c|c|c|}
\hline S.N. & Name & Plant part & Reference \\
\hline 43 & 8-methoxy kaempferol-3-O-glucoside & SB & Nazif, 2007 \\
\hline 44 & Kaempferol-3-O-glucoside & SB & $\begin{array}{c}\text { Nazif, } 2007 \\
\text { Ngnameko et al., } 2020\end{array}$ \\
\hline 45 & Kaempferol 3-O-(2-O- $\beta$-D-xylopyranosyl)- $\beta$-D-galactopyranoside & $\mathrm{L}$ & Gouda, 2009b \\
\hline 46 & Kaempferol 3-O-(2-O- $\beta$-D-glucopyranosyl)- $\beta$-D-glucopyranoside & $\mathrm{L}$ & Elusiyan et al., 2011 \\
\hline 47 & Kaempferol 3-O-(6-O- $\alpha$-L-rhamnopyranosyl)- $\beta$-D-galactopyranoside & $\mathrm{L}$ & Gouda, 2009b \\
\hline 48 & Kaempferol 3-O- $\beta$-D-(6-O- $\alpha$-L rhamnopyranosyl)- $\beta$-D-glucopyranoside & $\mathrm{L}$ & Gouda, 2009b \\
\hline 49 & Dihydrokaempferol-7-O-(2"-O-formyl)-ß-D-glucopyranoside & $\mathrm{L}$ & Gormann et al., 2006 \\
\hline 50 & Quercetin-3-O-(2-O- $\beta$-D-xylopyranosyl)- $\beta$-D-galactopyranoside & $\begin{array}{l}\mathrm{L} \\
\mathrm{L}\end{array}$ & $\begin{array}{c}\text { Gouda, 2009b } \\
\text { Santos et al., } 2020\end{array}$ \\
\hline 51 & $5,6,4$ '-trihydroxy flavonol-7-O- $\alpha$-rhamnopyranoside & $\mathrm{F}$ & Shehab et al., 2014 \\
\hline 52 & Apigenin & $\mathrm{L}$ & Gormann et al., 2006 \\
\hline 53 & Luteolin & $\mathrm{L}$ & Gormann et al., 2006 \\
\hline 54 & Diosmetin & $\mathrm{L}$ & Gormann et al., 2006 \\
\hline 55 & Naringenin & $\mathrm{F}$ & Shehab et al., 2014 \\
\hline 56 & Chrysin & $\mathrm{F}$ & Shehab et al., 2014 \\
\hline 57 & Rutin & $\mathrm{L}$ & Santos et al., 2020 \\
\hline 58 & Isoorientin & $\mathrm{F}$ & Santos et al., 2020 \\
\hline 59 & Vitexin & $\mathrm{L}, \mathrm{F}$ and $\mathrm{N}$ & Santos et al., 2020 \\
\hline \multirow[t]{2}{*}{60} & Orientin & $\mathrm{L}$ and $\mathrm{F}$ & Santos et al., 2020 \\
\hline & Carotenoids & & \\
\hline 61 & Lutein & $\mathrm{L}$ and $\mathrm{F}$ & Santos et al., 2020 \\
\hline 62 & Trans-Lutein & $\mathrm{N}$ & Santos et al., 2020 \\
\hline \multirow[t]{2}{*}{63} & Zeaxanthin & $\mathrm{L}$ & Santos et al., 2020 \\
\hline & Cryptoxanthin & $\mathrm{F}$ & Santos et al., 2020 \\
\hline 64 & 13-Cis $\beta$-carotene & $\mathrm{L}$ and $\mathrm{F}$ & Santos et al., 2020 \\
\hline 65 & $\alpha$-carotene & $\mathrm{L}$ and $\mathrm{F}$ & Santos et al., 2020 \\
\hline 66 & Trans- $\beta$-carotene & $\mathrm{L}, \mathrm{F}$ and $\mathrm{N}$ & Santos et al., 2020 \\
\hline \multirow[t]{2}{*}{67} & 9-Cis- $\beta$-carotene & $\mathrm{L}$ and $\mathrm{F}$ & Santos et al., 2020 \\
\hline & Monoterpenoids & & \\
\hline 68 & $\alpha$-pinene & $\mathrm{F}$ & Eid et al., 2014 \\
\hline 69 & Camphene & $\mathrm{F}$ & Eid et al., 2014 \\
\hline 70 & $\beta$-Myrcene & $\mathrm{F}$ & Eid et al., 2014 \\
\hline 71 & $\beta$-Pinene & $\mathrm{F}$ & Eid et al., 2014 \\
\hline 72 & $\alpha$-Phellandrene & $\mathrm{F}$ & Eid et al., 2014 \\
\hline 73 & Limonene & $\mathrm{F}$ & Eid et al., 2014 \\
\hline
\end{tabular}




\begin{tabular}{|c|c|c|c|}
\hline S.N. & Name & Plant part & Reference \\
\hline \multirow[t]{2}{*}{74} & $\beta$-Phellandrene & $\mathrm{F}$ & Eid et al., 2014 \\
\hline & Sequiterpenoids & $\mathrm{F}$ & \\
\hline 75 & $\alpha$-Copaene & $\mathrm{F}$ & Eid et al., 2014 \\
\hline 76 & $\beta$-Elemene & $\mathrm{F}$ & Eid et al., 2014 \\
\hline 77 & Longifolene & $\mathrm{F}$ & Eid et al., 2014 \\
\hline 78 & $\alpha$-Cedrene & $\mathrm{F}$ & Eid et al., 2014 \\
\hline 79 & $\alpha$-Guaiene & $\mathrm{F}$ & Eid et al., 2014 \\
\hline 80 & $\beta$-selinene & $\mathrm{F}$ & Eid et al., 2014 \\
\hline 81 & Aromadendrene & $\mathrm{F}$ & Eid et al., 2014 \\
\hline 82 & Viridiflorene & $\mathrm{F}$ & Eid et al., 2014 \\
\hline 83 & trans-Calamenene & $\mathrm{F}$ & Eid et al., 2014 \\
\hline \multirow[t]{2}{*}{84} & Cadalene & $\mathrm{F}$ & Eid et al., 2014 \\
\hline & Diterpenoids & & \\
\hline \multirow[t]{2}{*}{85} & Abietatriene & $\mathrm{F}$ & Eid et al., 2014 \\
\hline & Miscellaneous compounds & & \\
\hline 86 & Coumarin & $\mathrm{F}$ & Shehab et al., 2014 \\
\hline 87 & 5,7-Dihydroxy-4-Metilcoumarin & B & Ngnameko et al., 2020 \\
\hline 88 & Atranorin & SB & Niyonzima et al., 1991 \\
\hline 89 & Gallic acid & $\mathrm{F}$ & Santos et al., 2020 \\
\hline 90 & Ellagic acid & $\mathrm{F}$ & Shehab et al., 2014 \\
\hline 91 & Vanillic acid & $\mathrm{SB}$ & Niyonzima et al., 1991 \\
\hline \multirow[t]{2}{*}{92} & Syringic acid & $\mathrm{F}$ & Shehab et al., 2014 \\
\hline & & $\mathrm{RP}$ & Pianaro et al., 2007 \\
\hline \multirow[t]{2}{*}{93} & p-hydroxy-benzoic acid & & Mbosso et al., 2008 \\
\hline & & B & Ngnameko et al., 2020 \\
\hline \multirow{2}{*}{94} & \multirow{2}{*}{ Methyl p-hydroxy-benzoate } & $\mathrm{RP}$ & Pianaro et al., 2007 \\
\hline & & $\mathrm{B}$ & Ngnameko et al., 2020 \\
\hline 95 & 1,2-Benzenedicarboxylic acid, diisooctyl ester & $\mathrm{B}$ and $\mathrm{F}$ & Eid et al., 2014 \\
\hline 96 & 6-Benzofuran carboxyaldehyde & $\mathrm{B}$ and $\mathrm{F}$ & Eid et al., 2014 \\
\hline 97 & $\alpha$-Methyl cinnamaldehyde & $\mathrm{F}$ & Shehab et al., 2014 \\
\hline 98 & Phenylethanol esters & $\mathrm{F}$ & Shehab et al., 2014 \\
\hline \multirow[t]{2}{*}{99} & Phytol & F & Shehab et al., 2014 \\
\hline & & $\mathrm{L}$ & Elusiyan et al., 2011 \\
\hline 100 & 1,1-Diethoxy-3-methyl- Butane & $\mathrm{B}$ and $\mathrm{F}$ & Eid et al., 2014 \\
\hline 101 & n-Hexadecanoic acid & $\mathrm{B}$ and $\mathrm{F}$ & Eid et al., 2014 \\
\hline 102 & 9,12 -Octadecadienoic acid & $\mathrm{B}$ and $\mathrm{F}$ & Eid et al., 2014 \\
\hline
\end{tabular}

AP-Aerial Part; B-Bark; SB-Stem bark; F-Flowers; L-Leaf; R-Root; N-Nectar; S-Stem. 
Table 4. Biological activity of phytochemicals isolated from S. campanulate.

\begin{tabular}{|c|c|c|c|c|}
\hline Phytochemical & Bioactivity & Study model & Dose & References \\
\hline \multirow[t]{5}{*}{ Ursolic acid } & Antimalarial & Fink and Kretschmar's test & $60 \mathrm{mg} / \mathrm{kg} /$ day & Amusan et al., 1996 \\
\hline & & & (96.9\% suppression & \\
\hline & & & of & \\
\hline & & & parasitaemia & \\
\hline & & Rane test & $\begin{array}{l}60 \mathrm{mg} / \mathrm{kg} / \text { day (24 day mean } \\
\text { survival time) }\end{array}$ & Amusan et al., 1996 \\
\hline \multirow[t]{5}{*}{ Tomentosolic acid } & Antimalarial & Fink and Kretschmar's test & $40 \mathrm{mg} / \mathrm{kg} /$ day & Amusan et al., 1996 \\
\hline & & & (81.97\% suppression & \\
\hline & & & of & \\
\hline & & & parasitaemia & \\
\hline & & Rane test & $\begin{array}{c}40 \mathrm{mg} / \mathrm{kg} / \text { day ( } 18.4 \text { day } \\
\text { mean survival time) }\end{array}$ & Amusan et al., 1996 \\
\hline \multirow[t]{5}{*}{ 20ß-hydroxyursolic acid } & Antimalarial & Fink and Kretschmar's test & $80 \mathrm{mg} / \mathrm{kg} /$ day & Amusan et al., 1996 \\
\hline & & & (52.5\% suppression & \\
\hline & & & of & \\
\hline & & & parasitaemia & \\
\hline & & Rane test & $\begin{array}{c}40 \mathrm{mg} / \mathrm{kg} / \text { day (16.4 day } \\
\text { mean survival time) }\end{array}$ & Amusan et al., 1996 \\
\hline \multirow[t]{2}{*}{ 1-O-(E)-caffeoyl- $\beta$-gentiobiose } & Anti-inflammatory & $\begin{array}{l}\text { Stabilization of red blood cell } \\
\text { membrane }(65.91 \%)\end{array}$ & $\mathrm{EC}=50 \mu \mathrm{g} / \mathrm{ml}$ & Boniface et al., 2014 \\
\hline & Antioxidant & Radical-scavenging activity & $\mathrm{RS}_{50}=2.67 \mu \mathrm{g} / \mathrm{ml}$ & Boniface et al., 2015 \\
\hline $\begin{array}{l}\text { (2S)-1,2-di-O-[(9Z,12Z,15Z)- } \\
\text { octadeca-9,12,15-trienoyl]-3-O-[ } \alpha \text { - } \\
\text { D-galctopyranosyl-(1" } \rightarrow 6 \text { - })-O-\beta-D- \\
\quad \text { galactopyranosyl] glycerol }\end{array}$ & Anti-inflammatory & $\begin{array}{l}\text { Stabilization of red blood cell } \\
\text { membrane }(67.41 \%)\end{array}$ & $\mathrm{EC}=50 \mu \mathrm{g} / \mathrm{ml}$ & Boniface et al., 2014 \\
\hline \multirow[t]{2}{*}{ 6-O-caffeoylcatalpol (Verminoside) } & Antioxidant & DPPH assay & $\mathrm{EC}_{50}=2.04 \mu \mathrm{g} / \mathrm{ml}$ & Elusiyan et al., 2011 \\
\hline & Antioxidant & Radical-scavenging activity & $\mathrm{RS}_{50}=2.5 \mu \mathrm{g} / \mathrm{ml}$ & Boniface et al., 2015 \\
\hline Specioside & Antioxidant & DPPH assay & $\mathrm{EC}_{50}=17.44 \mu \mathrm{g} / \mathrm{ml}$ & Elusiyan et al., 2011 \\
\hline Kaempferol & Antibacterial & H. pyroli & $\mathrm{MBC}=28-56 \mu \mathrm{M}$ & Ngnameko et al., 2020 \\
\hline Kaempferol 3-O-(2-O- $\beta$-D- & Antioxidant & DPPH assay & $\mathrm{EC}_{50}=8.87$ & Elusiyan et al., 2011 \\
\hline glucopyranosyl)- $\beta$-D-glucopyranoside & & & $\mu \mathrm{g} / \mathrm{ml}$ & \\
\hline Campanulatoside & Antioxidant & DPPH assay & $\mathrm{IC}_{50}=49.2-52.21 \mu \mathrm{g} / \mathrm{ml}$ & Magnibou et al., 2021 \\
\hline \multirow[t]{2}{*}{ p-hydroxy-benzoic acid (93) } & Antifungal & Cladosporium herbarum & $\mathrm{EC}=100 \mu \mathrm{g}$ & Pianaro et al., 2007 \\
\hline & Antibacterial & Bacillus subtilis & $\mathrm{MIC}=3.12 \mu \mathrm{g}$ & Mbosso et al., 2008 \\
\hline Methyl p-hydroxy-benzoate (94) & Antifungal & C. herbarum & $\mathrm{EC}=100 \mu \mathrm{g}$ & Pianaro et al., 2007 \\
\hline Spathoside (35) & Antibacterial & B. cereus & $\mathrm{MIC}=6.3 \mu \mathrm{g}$ & Mbosso et al., 2008 \\
\hline & & K. pneumoniae & $\mathrm{MIC}=6.3 \mu \mathrm{g}$ & \\
\hline \multirow{2}{*}{$\begin{array}{c}\beta \text {-sitosterol-3-O- } \beta \text {-D-glucopyranoside } \\
(22)\end{array}$} & Antibacterial & Streptococcus faecalis & $\mathrm{MIC}=6.3 \mu \mathrm{g}$ & Mbosso et al., 2008 \\
\hline & & P. aeruginosa & $\mathrm{MIC}=3.2 \mu \mathrm{g}$ & \\
\hline$\beta$-sitosterol-3-acetate & Antibacterial & P. aeruginosa & $\mathrm{MIC}=6.3 \mu \mathrm{g}$ & \\
\hline Oleanolic acid (17) & Antibacterial & P. aeruginosa & $\mathrm{MIC}=6.3 \mu \mathrm{g}$ & Mbosso et al., 2008 \\
\hline Pomolic acid (19) & Antibacterial & P. aeruginosa & $\mathrm{MIC}=3.2 \mu \mathrm{g}$ & Mbosso et al., 2008 \\
\hline Phenylethanol esters & Antibacterial & S. flexneri & $\mathrm{MIC}=12.5 \mu \mathrm{g}$ & Mbosso et al., 2008 \\
\hline
\end{tabular}




\begin{tabular}{|c|c|c|c|c|}
\hline Phytochemical & Bioactivity & Study model & Dose & References \\
\hline \multirow[t]{2}{*}{ Campanulatoside } & Antibacterial & S. epidermidis & $\mathrm{MIC}=1.56 \mu \mathrm{g}$ & Magnibou et al., 2021 \\
\hline & & C. albicans & $\mathrm{MIC}=3.12 \mu \mathrm{g}$ & \\
\hline $\begin{array}{l}\text { Urs-12-en-27 } \alpha, 30 \text { dioic acid 3-O- } \alpha \text { - } \\
\text { L-rhamnopyranosyl }(1 \rightarrow 2) \alpha-\mathrm{L}- \\
\text { arabinopyranoside }\end{array}$ & Anticonvulsant & $\begin{array}{l}\text { PTZ and electrically-induced } \\
\text { seizures in rats }\end{array}$ & $100 \mathrm{mg} / \mathrm{kg}$ & Ilodigwe et al., 2010b \\
\hline Stigmasta-5,22-dien-3-ol & Anticancer & HL-60 cell line & $\mathrm{IC}_{50}=44.12 \mu \mathrm{g}$ & Wagh et al., 2021 \\
\hline Octadecenamide & Anticancer & HL-60 cell line & $\mathrm{IC}_{50}=35.65 \mu \mathrm{g}$ & Wagh et al., 2021 \\
\hline Umbelliferone & Anticancer & HL-60 cell line & $\mathrm{IC}_{50}=80.60 \mu \mathrm{g}$ & Wagh et al., 2021 \\
\hline
\end{tabular}

of $S$. campanulata in the experimental burn model in rats. The extract in ointment form $(2 \%, 10 \%$, and $49 \%)$ reduced the score damage at the burn site. The application of $49 \%$ extract changed the score damage from 5 to 0.2 after 15 days of experimental burn. It completely healed the burn on the $19^{\text {th }}$ or $20^{\text {th }}$ day (Sy et al., 2005). The activity was further validated in terms of its antimicrobial, antioxidant, and inhibition of nuclear factor kappa light chain enhancer of activated B cells (NF-KB) activity. It indicated antimicrobial activity against Trichophyton species. It diminished the peroxidation of bovine brain extract and showed the $\mathrm{IC}_{50}$ value of $0.24 \mu \mathrm{g} / \mathrm{ml}$. It also manifested a notable antioxidant effect by protecting MRC-5 cells from $\mathrm{H}_{2} \mathrm{O}_{2}$-induced oxidation damage at $1-10 \mu \mathrm{g} / \mathrm{ml}$. During antioxidant activity using liposomes, it exhibited an $\mathrm{IC}_{50}$ of $0.24 \mathrm{mg} / \mathrm{ml}$. The lowest concentration of $1 \mu \mathrm{g} / \mathrm{ml}$ demonstrated better protection against oxidative damage. Nevertheless, when cells were treated with high concentrations of the extract ( 5 and $10 \mu \mathrm{g} / \mathrm{ml})$, they indicated characteristic signs of cell damage probably due to cytotoxicity. On the other hand, the extracts did not show inhibition of NF-KB at $100 \mu \mathrm{g} / \mathrm{ml}$ (Mensah et al., 2006). The wound healing activity of MBE of $S$. campanulata was evaluated in excision wound model in Sprague Dawley rats. The extract was included into a cream $(10 \%$ and $20 \% \mathrm{w} / \mathrm{w})$ and put on the excision wounds. The wounds were further infected with Staphylococcus aureus. Treatment with the $20 \% \mathrm{w} / \mathrm{w}$ cream led to a rapid decrease in wound size. $95 \%$ of the uninfected wound was healed on the $20^{\text {th }}$ day and complete healing was observed on the $24^{\text {th }}$ day. In infected wounds, application of the $20 \% \mathrm{w} / \mathrm{w}$ cream led to $91 \%$ wound healing on the $24^{\text {th }}$ day and complete wound closure on the $28^{\text {th }}$ day (Ofori-Kwakye et al., 2011).

The experimentations related to wound healing nature of the plant have been supportive in the conventional use of the plant as a wound healer. However, the plant extract was proved to be most effective at lower dose because higher dose leads to cell damage probably due to cytotoxicity. More detailed safety data pertaining to dose of crude extracts need to be generated.

\section{Antibacterial and antifungal activity}

The antibacterial activity of methanolic leaf extract (MLE) of $S$. campanulata was determined utilizing the disk diffusion method, against $S$. aureus and Escherichia coli. The extract does not show significant activity (Melendez and Capriles, 2006). Various concentrations $(2.5-10 \mathrm{mg} / \mathrm{ml})$ of the organic leaf extracts were evaluated for antibacterial activity against eight bacteria employing agar disk diffusion assay method. The extracts displayed significant activity on the tested bacterial strains in a dose-dependent manner. The Gram-negative bacterium, Klebsiella pneumoniae was discovered to be more vulnerable to petroleum ether leaf extract with an inhibition zone of $11 \mathrm{~mm}$. However, the Gram-positive strains were found be least active (Dhanabalan et al., 2008). The antibacterial activity of seven isolated compounds from stem bark were assessed against Gram +ve and -ve bacteria using micro-broth dilution method. The tested compounds exerted significant antibacterial properties. Spathoside (35) hampered the growth of $K$. pneumoniae [minimum inhibitory concentration $(\mathrm{MIC})=6.25 \mathrm{mg} / \mathrm{ml}]$, Shigella flexneri $(\mathrm{MIC}=12.5 \mathrm{mg} / \mathrm{ml})$, and Bacillus subtilis (MIC $=25 \mathrm{mg} / \mathrm{ml})$. However, it did not inhibit the growth of Shigella dysenteriae and E. coli (Mbosso et al., 2008). ALE was evaluated for in vitro antibacterial activity against 14 pathogenic bacteria by cup plate method and it was found to be inactive (Satish et al., 2008). Aqueous and alcoholic extracts of the aerial parts were subjected to screening for antibacterial activity against three Staphylococcus species: Staphylococcus epidermidis, S. aureus, and Neisseria subflava using disk and well diffusion methods. The alcoholic extract was found to be more effective than aqueous extracts (Parekh and Chanda, 2008). The ALE and MLE of $S$. campanulata were investigated by disk and well diffusion methods against bovine udder isolated bacteria. MLE showed 8.0 and $7.6 \mathrm{~mm}$ inhibition zones against $S$. aureus and Streptococcus agalactiae, respectively (Das et al., 2009). The antibacterial activity of petroleum ether, ethanol, methanol, and aqueous stem bark extracts (ABE) of $S$. campanulata were investigated in case of $S$. aureus, B. subtilis, Pseudomonas aeruginosa, and $E$. coli. The MBE showed very good antibacterial activity. The MIC of MBE was found to be B. subtilis (50-55 $\mathrm{mg} / \mathrm{ml})$, S. aureus $(145-150 \mathrm{mg} / \mathrm{ml})$, P. aeruginosa $(60-65 \mathrm{mg} /$ $\mathrm{ml})$, E. coli $(50-55 \mathrm{mg} / \mathrm{ml})$, and Candida albicans $(45-50 \mathrm{mg} /$ $\mathrm{ml}$ ) (Ofori-Kwakye et al., 2009). EFE and ethanolic leaf extract (ELE) were evaluated for antibacterial activity at $10 \mathrm{mg} / \mathrm{ml}$ by using disk diffusion method against E. coli, S. aureus, B. subtilis, K. pneumonia, Proteus vulgaris, Salmonella typhimurium, and Vibrio cholera. The EFE was found to be more active than ELE (Kowti et al., 2010). The antibacterial assay of aqueous and ethanol extracts of roots, leaves, stem, and flowers of $S$. campanulata were evaluated by agar disk and well diffusion methods. EFE of $S$. campanulata exerted significant zone of inhibition against $E$. coli (7.5 mm), S. aureus (7 mm) (Kumar, 2012). MLE and ALE of $S$. campanulata were evaluated against nine bacterial species and two fungal species. MLE at a $200 \mu \mathrm{g} / \mathrm{ml}$ concentration showed inhibition zone of $18 \mathrm{~mm}$ against $S$. pneumonia and $14 \mathrm{~mm}$ for $S$. 
aureus, respectively. The ALE demonstrated inhibition zone of 9 $\mathrm{mm}$ for $S$. aureus and $8 \mathrm{~mm}$ for $E$. coli (Vijayasanthi and Kannan, 2014). ELE of the plant showed activity against $S$. typhi $(\mathrm{MIC}=$ $1,024 \mu \mathrm{g} / \mathrm{ml}$ ) in microdilution assay method (Roger et al., 2015). The methanolic flower extract (MFE) of $S$. campanulata showed strong activity against Enterococcus faecalis $(\mathrm{MIC}=39.1)$ and $K$. pneumonia $(\mathrm{MIC}=156.2 \mathrm{mg} / \mathrm{ml}$ ) (Mbosso et al., 2016). $70 \%$ of the hydroethanolic extracts of $S$. campanulata root were screened against Mycobacterium ulcerans and Mycobacterium smegmatis using the Resazurin Microtiter Assay (REMA). The MIC were observed at $250 \mu \mathrm{g} / \mathrm{ml}$ and $>250 \mu \mathrm{g} / \mathrm{ml}$, respectively (Fokou et al., 2016). The antibacterial activity of petroleum ether, chloroform, ALE, and nanoparticle obtained were determined against Bacillus cereus and Actinomyces pseudofradea using well diffusion method. Both the silver nanoparticles and chloroform extract were very effective against $A$. pseudofradea showing an inhibition zone of $21.50 \mathrm{~mm}$ at a concentration of $100 \mathrm{mg} / \mathrm{ml}$ (Rai et al., 2017). MIC of MLE and methanol root extract (MRE) of $S$. campanulata was obtained for B. cereus, B. subtilis, Proteus mirabilis, $S$. typhi, and C. albicans. Good activity was observed against $S$. typhi at MIC value of $400 \mu \mathrm{g} / \mathrm{ml}$. It also inhibited the growth of C. albicans at MIC of $400 \mu \mathrm{g} / \mathrm{ml}$. Antibacterial activities were more pronounced than antifungal potentials (Moronkola et al., 2018). ALE of $S$. campanulata was evaluated for their possible antifungal activity against eight species of Aspergillus such as Aspergillus niger, Aspergillus ochraceus, Aspergillus flavipes, Aspergillus candidus, Aspergillus columnaris, Aspergillus flavus, Aspergillus fumigatus, and Aspergillus tamari isolated from paddy, sorghum, and maize seeds. The aqueous extract was found to be inactive against the tested strains (Satish et al., 2007). Dried residue obtained from watery fluid at floral base of $S$. campanulata exhibited antimicrobial potency at a concentration of $500 \mu \mathrm{g}$ against different microorganisms (Killedar et al., 2011). EFE of S. campanulata displayed variable antibacterial activities with inhibition zones ranging from 16 to $25 \mathrm{~mm}$ in diameter against K. pneumonia, Streptococcus pyogenes, E. coli, and S. aureus at a concentration level of $100 \mu \mathrm{g} / \mathrm{ml}$ (Shehab et al., 2014). The in vitro antibacterial and antifungal activity of the fresh leaves extracts from $S$. campanulata was determined against bacterial species of Micrococcus luteus and Proteus vulagris and fungal strain of $A$. niger and $C$. albicans. The ALE exerted maximum inhibition with $17 \mathrm{~mm}$ against $M$. luteus, while the CLE showed an inhibition zone of $16 \mathrm{~mm}$ against C. albicans (Thampi and Kumar, 2015). 60\% aqueous MBE of Saccharomyces campanulata was observed to be inactive against E. coli, S. cerevisiae, and Penicillium crustosum (Taniguchi et al., 1978). The methanolic extract from aerial parts were screened for possible antibacterial activity against six Enterobacteriaceae strains. It was found to be most active against Enterobacter aerogenes and K. pneumonia (Parekh and Chanda, 2007). ALE and ABE from 0.5 to $2.5 \mathrm{mg} / \mathrm{ml}$ were investigated in an agar diffusion test against Helicobacter pylori, using amoxicillin as positive control. The extracts did not affect the bacterial growth in any of the test concentrations (Agyare et al., 2009). The dichloromethane/methanol $(1: 1, \mathrm{v} / \mathrm{v})$ crude bark extract and the fractions of were tested on H. pylori. The extract inhibited the growth of $H$. pylori by modulation of virulence factors and urease inhibition. One of the sub-fractions inhibited $H$. pylori urease in a heterologous bacterial model. Another sub-fraction had modulated the expression of one cytotoxin (CagA) and two adhesions (HopZ and BabA). Kaempferol (42) was identified as an active compound from the sub-fraction (Ngnameko et al., 2020).

The stem bark extract was found to be the most promising compared to other plant parts. Furthermore, the isolated compound, spathoside (35), was found to possess potent antibacterial activity in comparison to other isolated compounds. However, it was found to be less potent than the positive control ampicillin, which inhibited the growth of $B$. cereus and $S$. dysenteriae with MIC value of $0.4 \mathrm{mg} / \mathrm{ml}$. Although activities have been reported for leaves and flowers against wide ranges of bacteria and fungi, the study results are not encouraging in terms of the concentration investigated. Bearing in mind the results of antimicrobial activities, supplementary studies are required in connection with the widespread use in treatment of the skin infections, wound, including even chronic leg ulcer.

\section{Anthelmintic activity}

The MLE of $S$. campanulata was evaluated for anthelmintic efficacy against earthworms Pheretima posthuma at 5,15 , and $20 \mathrm{mg} / \mathrm{ml}$ concentrations. The paralysis time and death time were considered to know anthelmintic potency. Significant activity was observed at a concentration of $20 \mathrm{mg} /$ $\mathrm{ml}$. The paralysis time and death time were observed at 4.23 and 10.32 minutes, respectively (Wagh et al., 2019). The EFE showed significant anthelmintic effect at $100 \mathrm{mg} / \mathrm{ml}$ concentration against non-parasitic earthworms, Allolobophora caliginosa (Shehab et al., 2014).

The investigation upon anthelminthic study is preliminary as the parasite examined in the studies was only earthworm. Experiments on other helminths of human significance should be considered like tapeworm, hookworms, pinworms, and flukes. It may be summarized that there is a plenty of scope in assessing the plant for anti-helminthic activity.

\section{Anticancer activity}

MFE of S. campanulata exhibited weak antiproliferative effect against cancer cell lines of lung, glioma, and melanoma with a mean $\mathrm{IC}_{50}$ value above 92 and $78 \mathrm{mg} / \mathrm{ml}$, respectively (Mbosso et al., 2016). The antitumor activity of EFE of $S$. campanulata and its fractions was assessed in vitro against the two human cell lines MCF7 and hematocrit (HCT) 116 by the sulforhodamine B assay. EFE and its chloroform fraction demonstrated the $\mathrm{IC}_{50}$ values of 17.6 and $17.8 \mu \mathrm{g} / \mathrm{ml}$ against MCF7 cell line. Meanwhile, both hexane and $n$-butanol fractions showed identical $\mathrm{IC}_{50}(21.0 \mu \mathrm{g} / \mathrm{ml})$ against the cell line (Shehab et al., 2014). Aqueous, methanol, ethanol, and CLE of $S$. campanulata were screened for their anticancer activity in MCF-7 cells. The CLE inhibited 67.98\% proliferation on MCF-7 cells at $300 \mu \mathrm{g} / \mathrm{ml}$ (Dhanabalan et al., 2014). The cytotoxicity of the MRE was determined at different concentrations against drug-sensitive morphological variations in human leukemic lymphoblasts leukemia cells. $\mathrm{IC}_{50}$ was found to be more than $80 \mu \mathrm{g} / \mathrm{ml}$ (Kuete et al., 2016). The ELE showed very significant anticancer activity against Ehrlich-Lettre ascites carcinoma cell line $(85 \%)$ in comparison to ethyl acetate and chloroform extracts (Sangeetha et al., 2016). The anticancer activity of MBE was examined against three human leukemic cell lines K562, U937, and HL-60. The extract exhibited $\mathrm{IC}_{50}$ values of 19.45, 20.5, and 
$20.14 \mu \mathrm{g} / \mathrm{ml}$ against the respective cell lines. Characteristic features of apoptosis such as chromatin condensation, cell shrinkage, and membrane blebbing were observed on the treated cells. The extract lead to the arrest of cell cycle in the sub-G1 and G1 phases. Activation of Caspase 9 and 3 and reduction in Caspase 8 was the underlying reason of apoptosis (Kumar et al., 2020a). The apoptosis activity of MBE of $S$. campanulata was investigated on Hepatoma G2 (HepG2) cells. The extract inhibited cell viability in a concentration-dependent way significantly. Various signs of apoptosis like nuclear fragmentation, chromatin condensation, and development of apoptotic bodies were observed in treated cells. Cell cycle arrest was detected in the G0/G1 phase (Kumar et al., 2020b). Recently, the compounds stigmasta-5,22-dien-3ol, octadecenamide, and umbelliferone, isolated from chloroform extract of leaves of $S$. campanulate, were evaluated for their anticancer activity. The isolated compounds showed decreased cell viability in a dose-dependent manner against HL-60 cell lines. The $\mathrm{IC}_{50}$ values were found to be $44.12,35.65$, and $80.60 \mu \mathrm{g} / \mathrm{ml}$, respectively. However, the activity was low compared to positive control Adriamycin $(10.09 \mu \mathrm{g} / \mathrm{ml})$ (Wagh et al., 2021).

Concluding the anticancer activity, it may be observed that the flower extract showed potent anticancer activity. The extracts should have been considered for isolation of active principle and in-vivo investigation against a range of cell lines should have been taken up. The selectivity toward cancer cells should also have been measured out during anticancer activity.

\section{Anti-viral activity}

Different fractions of the SBD were evaluated for the anti-human immunodeficiency virus (HIV) activity. The extracts were rather moderately active compared to azidothymidine (Niyonzima et al., 1999). MLE was tested against three viruses, viz. herpes simplex, virus targets sindbis, and polio, and was found to be inactive (Anani et al., 2000). MLE and ALE of $S$. campanulata were quantitatively evaluated for HIV-1 protease inhibitory effect by high performance liquid chromatography (HPLC). The \%inhibition was found to be $42 \%$ and $31.1 \%$ at the concentration of $100 \mu \mathrm{g} / \mathrm{ml}$ (Takuya and Toru, 2009).

\section{Analgesic and anti-inflammatory activity}

The analgesic and anti-inflammatory activity of ELE of $S$. campanulata was determined using different pain models and carrageenan-induced acute inflammation in rats. $250-1,000 \mathrm{mg} / \mathrm{kg}$ of extract significantly increased the pain response times in hotplate and tail flick pain models, and decreased acetic acid-induced writhing (AIW) in a dose-dependent manner. It also demonstrated significant reduction of inflammation induced by carrageenan (Ilodigwe and Akah, 2009). The analgesic effect of EFE of $S$. campanulata was investigated via AIW test, formalin test, and tail immersion experimental model. Pre-treatment with 100$500 \mathrm{mg} / \mathrm{kg}$ extract caused noteworthy dose-related analgesic effect. In tail immersion test, $500 \mathrm{mg} / \mathrm{kg}$ dose significantly reduced the pain response with percentage inhibition of $230 \%$. The dose of $500 \mathrm{mg} / \mathrm{kg}$ inhibited $74.62 \%$ writhing induced by acetic acid when compared to control. In formalin-induced pain response, the dose of $500 \mathrm{mg} / \mathrm{kg}$ showed a significant percentage inhibition of 74.28\% (Lamaeswari and Anuradha, 2013a). Anti-inflammation efficiency of 1-O-(E)-caffeoyl- $\beta$-gentiobiose (30) and (2S)-
1,2-di-O-[(9Z,12Z,15Z)-octadeca-9,12,15-trienoyl]-3-O-[ $\alpha$-Dgalctopyranosyl-(1" $\left.\rightarrow 6^{\prime}\right)$-O- $\beta$-D-galactopyranosyl] glycerol (34) isolated from MLE of $S$. campanulata produced $65.91 \%$ and $67.41 \%$ of membrane stability, respectively. It was concluded that $S$. campanulata might have exhibited its anti-inflammatory response by soothing the RBC membrane. During in silico studies, the compounds exhibited good affinity toward cyclooxygenaseII (Boniface et al., 2014). The ALE and MLE of S. campanulata were screened for anti-inflammatory activity in rats. The extract in the dose of $200 \mathrm{mg} / \mathrm{kg}$ bw demonstrated noteworthy inhibition of paw edema $(0.431 \%)$ at the end of 180 minutes (Vijayasanthi et al., 2015).

Reliable analgesic activity of extracts obtained from leave and flowers were observed by both the methods. However, only alcoholic extracts were employed for the studies. The isolated compounds (30) and (34) showed almost equal anti-inflammatory activity as the standard anti-inflammatory agent diclofenac sodium, at a dose of $50 \mathrm{mg} / \mathrm{ml}$. Toxicity studies demonstrated that the compounds were free of toxicity. The compounds further exhibited good affinity toward cyclooxygenase-II enzyme during in silico studies. It may be summarized that there is an ample of scope in developing drug candidates from the plant for antiinflammatory activity.

\section{Antioxidant activity}

EFE of $S$. campanulata showed significant antioxidant activity. The extract demonstrated good activity during the superoxide radicals scavenging (SRS) and nitric oxide (NO) assay with $\mathrm{IC}_{50}$ values of 246 and $175 \mu \mathrm{g} / \mathrm{ml}$, respectively. Overall, antioxidant capacity was measured to be 50 and $500 \mu \mathrm{g} / \mathrm{ml}$. $500 \mu \mathrm{g} / \mathrm{ml}$ extract showed $74 \%$ and $79 \%$ inhibition during $\mathrm{NO}$ and superoxide radical (SR) scavenging assay. Standard drug curcumin exhibited $79 \%$ inhibition at $15 \mu \mathrm{g}$ concentration during NO scavenging activity and standard drug ascorbic acid displayed $89 \%$ inhibition at concentration of 100 $\mu \mathrm{M}$ in SRS assay (Hareesh et al., 2010a). EFE of S. campanulata exhibited a significant free radical scavenging activity toward the lipid hydroxyl radical (LHR), 2,2-diphenylpicrylhydrazyl (DPPH) radicals and lipid peroxidation (LP) inhibition, with $\mathrm{IC}_{50}$ values of 200,225 , and $201 \mu \mathrm{g} / \mathrm{ml}$, respectively. Maximum inhibition of $84 \%$, $68 \%$, and $82 \%$ were observed at $500 \mu \mathrm{g} / \mathrm{ml}$ concentration during LHR, DPPH radical scavenging, and LP inhibition assay, respectively. Standard drug butylated hydroxyanisole displayed $85 \%$ inhibition at a concentration of $400 \mu \mathrm{M}$ during LP inhibition assay and during DPPH radical inhibition assay, standard compound gallic acid showed $86 \%$ inhibition at $5 \mu \mathrm{g}$ concentrations (Hareesh et al., 2010b). The DNA damage preventing capacity of ELE and EFE of $S$. campanulata are studied by agarose gel electrophoresis method. Both extracts prevented the DNA damage induced by $\mathrm{H}_{2} \mathrm{O}_{2}$ and t-Butyl hydroperoxide. It showed protection up to $95 \%$ at $50 \mu \mathrm{g}$ concentration. Hence, it was experimentally proved that ethanol extract is very effective in preventing ROS-induced DNA damage (Kowti et al., 2011). The mechanism of antioxidant action was explored for $S$. campanulata bark and flower extracts. EFE and EBE exhibited antioxidant action on $\mathrm{LP}$ of liver microsome induced by $\mathrm{Fe}^{3+}$-ascorbic acid. The EFE was found to be five times less active than EBE. Flower extract, previously complexed with 20-100 $\mu \mathrm{M}$ concentrations of $\mathrm{Fe}^{3+}$, resulted in loss of antioxidant activity. However, previous incubation with $\mathrm{Fe}^{3+}$ did not lead to loss of antioxidant activity in bark extract. These experiments 
indicated an antioxidant mechanism independent of $\mathrm{Fe}^{3+}$ complex formation in case of bark extract. It was concluded that the antioxidant mechanisms of $S$. campanulata bark and flower extracts are divergent from each other, reflecting the extracts have diverse composition (Heim et al., 2012). Fresh leaves were analyzed for its antioxidant nature in terms of metal chelating ability, phosphomolybdenum assay, reducing power (RP) assay, and NO scavenging activity. Significant antioxidant activity justified the plant as a good source of antioxidant agents. However, the authors did not determine $\mathrm{IC}_{50}$ values for the assay carried out (Krishnaveni et al., 2013). Antioxidant activity of EFE of $S$. campanulata was determined by total antioxidant, NO scavenging activity, RP assay, and $\mathrm{H}_{2} \mathrm{O}_{2}$ scavenging activity. $\mathrm{IC}_{50}$ values observed for total antioxidant, NO scavenging activity, $\mathrm{H}_{2} \mathrm{O}_{2}$ scavenging activity and RP assay were $280,150,250$, and $220 \mu \mathrm{g} / \mathrm{ml}$, respectively. Similarly, the $\mathrm{IC}_{50}$ values for the standard drug ascorbic acid were observed at 250,100 , and $120 \mu \mathrm{g} / \mathrm{ml}$, respectively. This clearly indicates that the flower extract has highly effective antioxidant properties (Lamaeswari and Anuradha, 2013b). Verminoside (7) and 1-O-(E)-caffeoyl- $\beta$-gentiobiose (30) isolated from the leaves of $S$. campanulata displayed outstanding antioxidant activity with concentration required to produce $50 \%$ radical scavenging activity $\left(\mathrm{RS}_{50}\right)$ value of 2.5 and $2.67 \mu \mathrm{g} / \mathrm{ml}$ in DPPH radical scavenging assay. The antioxidant activity was greater than that of standard ascorbic acid $\left(\mathrm{RS}_{50}=3.25 \mathrm{mg} / \mathrm{ml}\right)$. The compounds act as a potential inhibitor of tyrosinase during in silico study, which is in line with the observed antioxidant activity (Boniface et al., 2015). In vitro antioxidant activities were shown by the petroleum ether, ethanol, methanol, and aqueous extracts in free radical (DPPH), hydroxyl scavenging activities and ferric-reducing antioxidant properties. During the in vivo antioxidant assay, improvement in enzymatic level of glutathione and catalase was observed, when mice infected with $S$. typhi were given ELE (Coolborn et al., 2015). Antioxidant activity of ALE was evaluated by $\mathrm{H}_{2} \mathrm{O}_{2}$ RP method. The aqueous extract showed $70.2 \%$ scavenging (Thampi and Kumar, 2015). 70\% ELE of S. campanulata demonstrated high antioxidant effect in terms of radical scavenging activity against DPPH (84.67\%), SR (72.69\%), $\mathrm{H}_{2} \mathrm{O}_{2}(83.20 \%)$, hydroxyl radicals (70\%), and phosphomolybdate RP (955 FAEA) in comparison to chloroform and ethyl acetate extracts. Ethanol extract also showed high level of total phenolic content (9.21 mg FAE/l), which is linked with the significant antioxidant activity (Sangeetha et al., 2016). Different fractions of MLE of S. campanulata were screened employing DPPH radical scavenging assay. They had considerable antioxidant potency at concentrations of 250-1,000 $\mu \mathrm{g} / \mathrm{ml}$. The highest antioxidant effect was observed for the hexane fraction with an $\mathrm{IC}_{50}$ of $178.46 \mu \mathrm{g} / \mathrm{ml}$ (Umenwa et al., 2017). The antioxidant activity and total phenolic content of leaves, flowers, and nectars of $S$. campanulata from different climatic regions and from different cities of Brazil were evaluated. In vitro antioxidant activity was carried out by ferric-reducing antioxidant power, oxygen radical absorbance capacity, and DPPH assay. The leaves and flowers of $S$. campanulata exerted significant antioxidant capacity and total phenols were independent of the city. The antioxidant activity and total phenolic content were high in flowers, leaves, and nectars, respectively (Santos et al., 2020).

It may be concluded that stem bark and flower and leaf extracts having iridoids, cinnamic acid, flavonoids, and phenolics are responsible for the antioxidant activity. The bark extract was found to be more potent than leaf extract. The underlined antioxidants not only acted as scavengers of free radicals but also prevented $\mathrm{H}_{2} \mathrm{O}_{2}$ and ROS-induced DNA damage. Hence, the plant can be strategically utilized to counteract the undesirable effects of oxidative stress. These natural antioxidants can be used as additives in food stuffs or to develop products such as nutraceuticals and/or functional foods to protect humans from various chronic diseases.

\section{Cardioprotective activity}

Cardioprotective effect of $70 \%$ EBE of S. campanulata was determined in Wister rats intoxicated with isoproterenol. Doses of 250 and $500 \mathrm{mg} / \mathrm{kg}$ were orally given for 14 days and cardioprotection was evaluated by estimating serum lactate dehydrogenase, aspartate amino transferase (AST), alanine amino transferase (ALT), creatin phosphokinase, cholesterol, high density lipoprotein, and low density lipoprotein. The observed results were further confirmed by analyzing levels of thiobarbituric acid reactive substance and reduced glutathione in heart homogenate. The prior administration of bark extract significantly prohibited the isoproterenol-induced cardiac alterations (Abubaker et al., 2012a).

\section{Nephroprotective activity}

Nephroprotective protective potential of $70 \%$ EBE of $S$. campanulata was evaluated on paracetamol-induced nephrotoxicity in rats. The extract was given for 7 days, at doses of 250 and $500 \mathrm{mg} / \mathrm{kg}$ po. Pre-treatment with the extract improved paracetamol-induced lipid peroxide formation and exhibited a decrease in serum marker enzymes. Ethanol extract also prohibited the reduction of tissue glutathione levels. Histopathological studies revealed a restoration of renal architecture (Abubaker et al., 2012b).

\section{Hepatoprotective activity}

The ABE of $S$. campanulata was investigated for hepatoprotective effect against acetaminophen-induced hepatic damage in mice. The mice were pretreated with 100, 300, and $625 \mathrm{mg} / \mathrm{kg}$ of the extract for 5 days prior to intoxication with acetaminophen. Hepatoprotective action was accessed by estimating ALT and AST levels in serum and total cytochrome P450, glutathione peroxidase, and superoxide dismutase levels in liver homogenate. Significant hepatoprotection was observed against liver damage as evident from decreased levels of marker enzymes and increased levels of total protein content in extracttreated groups. The extract reversed the decline in antioxidant enzymes; superoxide dismutase, and glutathione peroxidase levels. It also caused substantial inhibition of CYP450 enzymes responsible for activation of acetaminophen. The extract protected the liver by increasing antioxidant capacity and interfering with the bio-transformation of acetaminophen (Dadzeasah and Ansah, 2013). Hepatoprotective activity of ABE of $S$. campanulata was investigated in a carbon tetrachloride-induced hepatotoxicity model. Rats pre-treated with $625,1,250$, and 2,500 $\mathrm{mg} \mathrm{kg}^{-1}$ dose for 3 days showed significant hepatoprotective activity as marked from reduced serum levels of ALT, AST, gamma glutamyl transferase, and bilirubin in extract-treated groups. Hepatoprotective potential was well correlated with histopathological findings and the antioxidant capacity. LP assayed showed that the extract also restored significantly increased level of thiobarbituric acid reactive substances to near normal in the carbon tetrachloride- 
treated rats. Administration of the extract (po) also considerably inhibited cytochrome P450 enzymes and thus interfered with $\mathrm{CCl}_{4}$ bioactivation and demonstrated hepatoprotective action (Ansah et al., 2013). The hepatoprotective potential effect of the stem and root bark extracts of $S$. campanulata was evaluated on dimethylnitrosamine (DEN)-induced hepatic impairment in albino rats. Treatment with root and stem bark extracts of $S$. companulata significantly relieved the changes in the loss of body weight and transaminase activity induced by DEN (Uchenna et al., 2021).

\section{Larvicidal activity}

The MLE of $S$. campanulata was found to be most active with $\mathrm{LC}_{50}$ values of $1.343,1.607,1.981,2.165$, and 2.432 against stage I, II, III, and IV of larvae and pupa, respectively (Aarthi and Murugan, 2010). The effectiveness of ALE of $S$. campanulata leaves was evaluated against the dengue vector Aedes aegypti. Extract tested at $0.1 \%, 0.2 \%$, and $0.3 \%$ prolonged the larval and pupal period. The leaf extract showed $\mathrm{EI}_{50}$ and $\mathrm{EI}_{90}$ at $0.79 \%$ and $0.88 \%$ concentrations, respectively (Saranya et al., 2013a). Larvicidal and pupicidal activities and morphological deformities against Aedes aegypti were investigated for ALE of $S$. campanulata. $\mathrm{LC}_{10}, \mathrm{LC}_{50}$, and $\mathrm{LC}_{90}$ values at different time periods against I instar larvae were observed to be $1.42 \%, 4.0 \%$, and $5.40 \%$ (24 hours); $0.47 \%, 0.96 \%$, and $2.12 \%$ (48 hours); $0.28 \%$, $1.14 \%$, and $1.84 \%$ (72 hours); and $0.14 \%, 0.59 \%$, and $1.12 \%$ (96 hours). Moreover, various morphological changes were observed at different stages of development (Saranya et al., 2013b).

The plant has great significance in designing of an efficient vector control strategy based on environmental benign alternative to synthetic larvicides due to its ability to kill various stages of the larvae.

\section{Insecticidal activity}

The insecticidal potential of $S$. campanulata nectar was assessed through mortality tests on Sitophilus zeamais. The pure nectar showed a control efficiency of $89 \%$ against the insect population (Franco et al., 2015). Insecticidal action of nectar from $S$. campanulata was tested against three different insects. viz. Helicoverpa zea, Euschistus heros, and Anticarsia gemmatalis. The activity was linked to pro-oxidant proteins present in the nectar. The gross nectars and the dialysate nectar exhibited a mortality of $60 \%, 35 \%$ against $E$. heros, respectively. The gross nectar offered the highest mortality $(80 \%)$ against $H$. zea in comparison to dialysate nectar (55\%) (Santos et al., 2017).

Natural products such as $S$. campanulata nectar could be considered as a replacement to chemical pesticides due to their lower perseverance in the environment. Therefore, $S$. campanulata nectar could be used to protect grains while in storage due to its ability to kill various insects and pests.

\section{Anticonvulsant activity}

The anticonvulsant activity of ELE was studied using picrotoxin, pentylenetetrazole (PTZ), and electroshock-induced mice models. Prior administration of $S$. campanulata extract (250-1,000 $\mathrm{mg} / \mathrm{kg}$ po) protected the mice against PTZ and picrotoxin-induced convulsion. $100 \%$ protection was observed at the maximum dose of $1,000 \mathrm{mg} / \mathrm{kg}$. Administration of the extract did not significantly affect centrally coordinated behaviors such as rota-rod performance, righting reflex, position sense, amphetamine-induced stereotypy, and phenobarbital sleep time in treated animals. The results also showed that $S$. campanulata extract is non-sedating and has no antipsychotic properties (Ilodigwe et al., 2010a). Anticonvulsant effect of the isolated glycoside, urs-12-en-27 $\alpha, 30$ dioic acid 3-0- $\alpha$-Lrhamnopyranosyl $(1 \rightarrow 2) \alpha$-L-arabinopyranoside (20), from ELE of $S$. campanulata was determined using PTZ and electrically induced seizures. The consequence on phenobarbitone-induced sleeping time and rotarod performance were also experimented. It exhibited significant eradication of seizures caused by PTZ and electro shock. Oral and intraperitoneal $\mathrm{LD}_{50}$ of 323.59 and $158 \mathrm{mg} / \mathrm{kg}$ were obtained during acute toxicity studies, respectively (Ilodigwe et al., 2010b).

From the experimental study, it can be concluded that ethanol leaf extract of $S$. campanulata exhibits significant anticonvulsant activity against PTZ and picrotoxin-induced convulsion in Swiss albino mice. The anticonvulsant activity was attributed to the glycoside (20) present. This study provides pharmacological evidence for the folk claim of this plant to treat mental disorder and insanity. Furthermore, there is scope to derive the possible mechanism involved. The roots and barks can be studied for analogous activities, as they are traditionally prescribed for convulsion.

\section{Antidepressant activity}

The methanolic flower extract of $S$. campanulata was evaluated for antidepressant activity in mice at doses of 200 and $400 \mathrm{mg} / \mathrm{kg}$. It showed dose-dependent antidepressant activity in tail suspension test, force swim test, and lithium chloride-induced twitches test. The extract significantly decreased in immobility period. Furthermore, a significant reduction in head twitches and locomotor activity was observed after giving the extract. The HPLC/electrospray ionisation mass spectrometry study identified the existence of spathoside A (3) and spathoside B (4) in the extract. These two compounds showed good binding affinity for monoamine oxidase A enzyme (Bajaj et al., 2021).

\section{Sedative and anxiolytic activities}

The sedative and anxiolytic activities of methanol leaf extract were evaluated in different animal models, viz. open field and hole-cross test, elevated plus maze, light-dark box, and holeboard test. In both open field and hole-cross tests, the extract at different doses of 200,400, and $600 \mathrm{mg} / \mathrm{kg}$ significantly reduced the number (squares and holes) crossed by mice. Moreover, the mice opted to stay more in open arms and light box instead of close arms and dark box in elevated plus maze and light-dark box tests, respectively. Furthermore, the hole-board test elevated the number of head dipping to a significant extent (Begum et al., 2020).

\section{Inhibition of sickling}

MFE was examined for in-vitro reverse sickling of erythrocytes at a low oxygen level according to the modified Dean and Schechter method. It displayed reversal activity of $89.6 \%$ at a concentration $4 \mathrm{mg} / \mathrm{ml}$ and inhibited polymerization of erythrocytes (Bamimore and Elujoba, 2018).

\section{Antiulcer activity}

Antiulcer activity of ELE of $S$. campanulata was determined against aspirin-induced gastric ulcer in rats. The 
extract at 200 and $400 \mathrm{mg} / \mathrm{kg}$ po decreased the ulcer index, ulcer number, gastric volume, $\mathrm{pH}$, total acidity, and free acidity. It confirmed that $S$. campanulata extract has anti-ulcer activity due to secondary metabolites (Khatri et al., 2019).

\section{Molluscicidal activity}

Molluscicidal properties were studied against the bilharzia carrying snails Bulinus africanus. MBE was found to be strongly molluscicidal (Amusan et al., 1995). Screening of $70 \%$ of the ethyl alcohol leaf extract of $S$. campanulata showed molluscicidal activity against snails. The activity was attributed to the presence of tannins (Shams et al., 2012).

\section{Aphrodisiac activity}

Aphrodisiac activity of ABE of $S$. campanulata was determined in male rats. The rats were given 200,400, and 800 $\mathrm{mg} / \mathrm{kg} \mathrm{ABE}$ for 8 days and the copulatory parameters were recorded. Bark extract increased the erectile function stimulation by increasing the number of erections, mount, and ejaculation frequency. These results proved the aphrodisiac properties of the trunk barks and justified the traditional use of this plant in curing erectile dysfunction (Clovis et al., 2019). To validate the traditional use of the bark as an aphrodisiac, the androgenic properties of the aqueous extract of $S$. campanulata trunk bark was evaluated in adult male rats. At the dose of $200 \mathrm{mg} / \mathrm{kg}$, the extract significantly increased the penile nitrogen monoxide $(136.36 \%)$ and the vesicular fructose $(19.58 \%)$. Furthermore, there was an increase in the weight of certain androgen-dependent organs: the prostate $(7.70 \%)$, the testes $(11.20 \%)$, and penis $(31.81 \%)$. These results validated the androgenic potential of $S$. campanulata and backing the use of $S$. campanulata trunk bark in the treatment of erectile dysfunction (Talla et al., 2021).

\section{UV absorption ability}

The flower extract of $S$. campanulata was screened for its cosmetic use. The extract absorbed UV radiation in the range of 200-400 $\mathrm{nm}$ and proved to possess UV protection ability (Patil et al., 2011). The flower extract prepared from distilled water and methanol (2:5) showed maximum absorbance at 200-240 nm, while good and moderate absorbances were noted at $240-325 \mathrm{~nm}$ and 310-340 nm, respectively (Patil et al., 2009).

\section{CLINICAL STUDIES}

One clinical study has been conducted to establish the effectiveness of $S$. campanulata for its use in malarial. Time Herbal Mixture ${ }^{\circledR}$ (THM), a Ghanaian herbal product composed of stem barks of S. campanulata, leaves of Solanum torvum, Vernonia amygdalina, and Bombax buonopozense, was evaluated to establish its safety and effectiveness in treatment of uncomplicated malaria. 40 patients diagnosed with uncomplicated malaria were given $60 \mathrm{ml}$ of the formulation, three times daily for 6 days. The participants were followed-up for a period of 28 days. These patients comprised 15 males and 25 females, with a mean age of 42.29 years. $82.50 \%$ (33) of the participants were completely cured by day 7 (clearance of all parasites achieved). Partial clearance was observed in six patients and treatment failure in one. The product was found to have good safety profile as none of them reported any side effects. Kidney, liver, and blood profiles were also usual after the study (Tetteh et al., 2020).

\section{TOXICITY STUDY}

Acute toxicity of ELE was studied by administering doses in the range of $1,000-5,000 \mathrm{mg} / \mathrm{kg}$. The subchronic study was carried out by giving $750-3,000 \mathrm{mg} / \mathrm{kg}$ of extract for 90 days. The $\mathrm{LD}_{50}$ of the extract was estimated to be $4,466.84 \mathrm{mg} /$ $\mathrm{kg}$. Deaths of animals were not observed during the study period but the rats had signs of weakness, sluggishness, anorexia, and increase in body weight. The extract significantly increased the serum liver enzymes, alkaline phosphatase (ALP), ALT, and AST. However, these changes were recovered after 28 days posttreatment. These outcomes suggest that the ELE of $S$. campanulata is safe in the treatment of various diseases (Ilodigwe et al., 2010c). Acute oral toxicity of the bark extract of $S$. campanulata was studied at a single oral dose of $2,000 \mathrm{mg} / \mathrm{kg}$. Various parameters like body weight, behavior, general appearance, and mortality were calculated. It did not cause changes in general appearance and mortality and was found to be safe at a dose of $2,000 \mathrm{mg} /$ $\mathrm{kg}$ (Palande, 2015). Toxicity profile of MBE was experimentally determined by both acute and sub-chronic toxicity studies in rats. Single oral dose of $5,000 \mathrm{mg} / \mathrm{kg}$ did not lead to any observable toxic effect or mortality. However, oral administration of the 800 $\mathrm{mg} / \mathrm{kg}$ dose for 90 days resulted in an increase in bodyweight (increase in the stomach). Among the biochemical parameters accessed [Gamma-glutamyl transferase (GGT), AST, ALT, ALP, urea, and creatinine], only ALT level was increased at the $800 \mathrm{mg} / \mathrm{kg}$ dose. The levels of RBC, WBC, HCT, and red cell distribution width reduced significantly at the $800 \mathrm{mg} / \mathrm{kg}$ dose in the extract-treated groups. However, a noteworthy increase in mean corpuscular hemoglobin $(\mathrm{MCH})$, mean corpuscular volume (MCV), and mean corpuscular hemoglobin concentration levels were observed at the $800 \mathrm{mg} / \mathrm{kg}$ dose in the treated animals. A histological analysis of the heart showed myocardial necrosis and hemorrhage at 400 and $800 \mathrm{mg} / \mathrm{kg}$ after 90 days administration. The acute use of extract was found to be safe. However, prolonged use at high doses affected liver enzyme (ALT) and the myocardial tissue (Tanayen et al., 2016). The cytotoxicity $(250 \mu \mathrm{g} / \mathrm{ml})$ of promising extracts was assayed on normal Chang liver cells by an (3-(4, 5-dimethylthiazolyl-2)-2, 5-diphenyltetrazolium bromide) assay (Fokou et al., 2016).

\section{CONCLUSION}

Spathodea campanulata has been used for centuries for the treatment of malaria, diabetes, ulcers, wounds, and skin infection. The preliminary experimentations related to conditions like malaria, wounds, inflammations, convulsions, and diabetes have been supportive in bringing about the relationship between the pharmacological activity and types of the phytochemicals involved. However, the exact mechanism of its actions pertaining to its therapeutic potential is still uncertain. Malaria is reported to be traditionally treated by this plant, which is now justified by the modern findings of ursolic acid and tomentosolic acid. $S$. campanulata plant phytochemicals can be very useful as a firstaid treatment of malaria in the remote areas of Africa and Asia where modern medicine is not easily accessible. Additionally, the mechanism of action studies would further support the antimalarial activity. In addition to the above-mentioned observation, studies connected to wound healing activities are more distinct in crude extract. The antioxidant and antimicrobial activities advocate that 
the utilization of the plants in wound healing may be based on antiseptic and antioxidant effects of its constituents, which lend support to its folkloric use in the management of wounds. The insecticidal and larvicidal study is of great significance in designing an efficient vector control strategy based on environmental benign alternatives to synthetic insecticides and larvicides. Some of the validation studies like asthma, facilitation of delivery, treatment of reproductive system, hernia, and antidote against animal poisons have not been touched upon. The reviewed literature designates some gap in scientific studies that needs consideration as claimed in the traditional system of medicine. Further high-quality clinical studies are necessary to provide definitive clinical evidence of safety and efficacy.

\section{ACKNOWLEDGMENT}

The author expresses his thanks to Dr. Chandra Sekhar Patro, Principal, School of Pharmacy, Centurion University of Technology and Management, Rayagada, Odisha, for providing the opportunity to carry out this work.

\section{AUTHOR CONTRIBUTIONS}

All authors made substantial contributions to conception and design, acquisition of data, or analysis and interpretation of data; took part in drafting the article or revising it critically for important intellectual content; agreed to submit to the current journal; gave final approval of the version to be published; and agree to be accountable for all aspects of the work. All the authors are eligible to be an author as per the international committee of medical journal editors (ICMJE) requirements/guidelines.

\section{FUNDING}

There is no funding to report.

\section{CONFLICTS OF INTEREST}

The authors report no financial or any other conflicts of interest in this work.

\section{ETHICAL APPROVALS}

This study does not involve experiments on animals or human subjects.

\section{PUBLISHER'S NOTE}

This journal remains neutral with regard to jurisdictional claims in published institutional affiliation.

\section{REFERENCES}

Aarthi N, Murugan K. Larvicidal and smoke repellent activities of Spathodea campanulata P. Beauv. against the malarial vector Anopheles Stephensi Lis (Diptera: Culicidae). J Phytol, 2010; 2:61-9.

Abdraboh NR, Ahmed, N. Comparative study of biochemical changes in alloxan induced diabetic mice treated with extracts of Spathodea campanulata flowering branch and barks. Res J Med Plant, 2015; 9:395405; doi:10.3923/rjmp.2015.395.405

Abubaker S, Shanmukha I, Jyoti TM, Gupt K. Cardioprotective effect of Spathodea campanulata bark on isoproterenol-induced myocardial infarction in rats. Asian Pacific J Trop Dis, 2012a; 2:S1-5; doi:10.1016/ S2222-1808(12)60113-3

Abubaker S, Shanmukha I, Rajendra SV, Ramachandra Setty S. Protective effect of Spathodea campanulata bark against paracetamolinduced nephrotoxicity in rats. Int J Pharm Tech Res, 2012b; 4:398-403.
Adebayo JO, Krettli AU. Potential antimalarials from Nigerian plants: a review. J Ethnopharmacol, 2011; 133:289-302; doi:10.1016/j. jep.2010.11.024

Adia MM, Anywar G, Byamukama R, Kamatenesi-Mugisha M, Sekagya Y, Kakudidi EK, Kiremire BT. Medicinal plants used in malaria treatment by Prometra herbalists in Uganda. J Ethnopharmacol, 2014; 155:580-8; doi:10.1016/j.jep.2014.05.060

Agyare C, Asase A, Lechtenberg M, Niehues M, Deters A, Hensel A. An ethnopharmacological survey and in vitro confirmation of ethnopharmacological use of medicinal plants used for wound healing in Bosomtwi-Atwima-Kwanwoma area, Ghana. J Ethnopharmacol, 2009; 125:393-403; doi:10.1016/j.jep.2009.07.024

Agyare C, Boakye YD, Bekoe EO, Hensel A, Dapaah SO, Appiah T. Review: African medicinal plants with wound healing properties. J Ethnopharmacol, 2016; 177:85-100; doi:10.1016/j.jep.2015.11.008

Agyare C, Spiegler V, Asase A, Scholz M, Hempel G, Hensel, A. An ethnopharmacological survey of medicinal plants traditionally used for cancer treatment in the Ashanti region, Ghana. J Ethnopharmacol, 2018; 212:137-52; doi:10.1016/j.jep.2017.10.019

Akinwumi IA, Sonibare MA. Use of medicinal plants for the treatment of gastric ulcer in some parts of Southwestern Nigeria. Afr J Pharm Pharmacol, 2019; 13:223-35.

Amusan OOG, Msonthi JD, Makhubu LP. Molluscicidal activity of Spathodea campanulata Andrachne ovalis, Phytolacca dodecandra and Hypoxis rooperi. Fitoterapia, 1995; 66:113-6.

Amusan OOG, Adesogan EK, Makinde JM. Antimalarial active principles of Spathodea campanulata stem bark. Phyther Res, 1996; 10:6923; doi:10.1002/(sici)1099-1573(199612)10:8<692::aid-ptr928>3.3.co;2-f

Anani K, Hudson JB, De Souza C, Akpagana K, Tower GHN, Arnason JT, Gbeassor M. Investigation of medicinal plants of Togo for antiviral and antimicrobial activities. Pharm Biol, 2000; 38:40-5; doi:10.1076/1388-0209(200001)3811-bft040

Ansah C, Dadzeasah PE, Asiamah E. Aqueous stem bark extract of Spathodea campanulata (P. Beauv) modulates carbon tetrachloride induced hepatic damage in rats. Am J Pharmacol Toxicol, 2013; 8:39-50; doi:10.3844/ajptsp.2013.39.50

Anywar G, Kakudidi E, Byamukama R, Mukonzo J, Schubert A, Oryem-Origa, H. Indigenous traditional knowledge of medicinal plants used by herbalists in treating opportunistic infections among people living with HIV/AIDS in Uganda. J Ethnopharmacol, 2020; 246:112205; doi:10.1016/j.jep.2019.112205

Appiah K, Oppong C, Mardani H, Omari R, Kpabitey S, Amoatey C, Onwona-Agyeman S, Oikawa Y, Katsura K, Fujii Y. Medicinal plants used in the Ejisu-Juaben Municipality, Southern Ghana: an ethnobotanical study. Medicines, 2019; 6:1; doi:10.3390/medicines6010001

Asase A, Oppong-Mensah G. Traditional antimalarial phytotherapy remedies in herbal markets in southern Ghana. J Ethnopharmacol, 2009; 126:492-9; doi:10.1016/j.jep.2009.09.008

Bajaj J, Dwivedi J, Sahu R, Dave V, Verma K, Joshi S, Sati B, Sharma S, Seidel V, Mishra AP. Antidepressant activity of Spathodea campanulata in mice and predictive affinity of spatheosides towards type A monoamine oxidase. Cell Mol Biol, 2021; 67(1):1-8; doi:10.14715/ $\mathrm{cmb} / 2021.67 .1 .1$

Bamimore V, Elujoba AA. Antisickling properties of three medicinal plants and their combinations. Int J Pharmacogn, 2018; 5:666-72.

Begum A, Biswas P, Shahed-Al-Mahmud M. Methanol extract of Spathodea campanulata P. (Beauv.) leaves demonstrate sedative and anxiolytic like actions on swiss albino mice. Clin Phytosci, 2020; 6(1):112; doi:10.1186/s40816-020-00182-z

Bekoe EO, Agyare C, Boakye YD, Baiden BM, Asase A, Sarkodie J, Nettey H, Adu F, Otu PB, Agyarkwa B, Amoateng P, AsieduGyekye I, Nyarko A. Ethnomedicinal survey and mutagenic studies of plants used in Accra metropolis, Ghana. J Ethnopharmacol, 2020; 248:112309; doi:10.1016/j.jep.2019.112309

Betti JL, Caspa R, Ambara J, Kourogue RL. Ethno-botanical study of plants used for treating malaria in a forest: savanna margin area, 
East region, Cameroon. Glob J Res Med Plants Indig Med, 2013; 2:692708.

Boniface PK, Verma S, Shukla A, Khan F, Srivastava SK, Pal A. Membrane stabilisation: a possible anti-inflammatory mechanism for the extracts and compounds from Spathodea campanulata. Nat Prod Res, 2014; 28:2203-7; doi:10.1080/14786419.2014.930858

Boniface PK, Singh M, Verma S, Shukla A, Khan F, Srivastava SK, Pal A. RP-HPLC-DAD method for the identification of two potential antioxidant agents namely verminoside and $1-\mathrm{O}-(\mathrm{E})$-caffeoyl- $\beta$-gentiobiose from Spathodea campanulata leaves. Nat Prod Res, 2015; 29:676-80; doi: 10.1080/14786419.2014.981538

Boniface PK. Advances on ethnomedicinal uses, phytochemistry, and pharmacology of Spathodea campanulata P. Beauv. EC Pharmacol Toxicol, 2017; 5:51-62.

Brown P, Daigneault A. Cost-benefit analysis of managing the invasive African tulip tree (Spathodea campanulata) in the Pacific. Environ Sci Policy, 2014; 39:65-76; doi:10.1016/j.envsci.2014.02.004

Bunalema L, Obakiro S, Tabuti JRS, Waako P. Knowledge on plants used traditionally in the treatment of tuberculosis in Uganda. J Ethnopharmacol, 2014; 151:999-1004; doi:10.1016/j.jep.2013.12.020

CABI. Spathodea campanulata. In: Invasive species compendium, $\mathrm{CAB}$ International, Wallingford, UK, 2021. Available via https://www.cabi.org/isc/datasheet/51139\#tosummaryOfInvasiveness

Clovis T, Yaya I, Nga N, Didier DS, Emmanuel MM. Evaluation of aphrodisiac properties of the aqueous extract of the trunk barks of Spathodea campanulata P. Beauv. (Bignoniaceae) on albino rats (Rattus norvegicus). J Med Plants Res, 2019; 13:480-6; doi:10.5897/jmpr2019.6741

Coolborn AF, Bolatito B, Omolara AV, Adetuyi F. Phytochemical and antioxidant effect of Spathodea campanulata leaf extracts. Int J Biochem Res Rev, 2015; 7:148-59; doi:10.9734/ijbcrr/2015/16371

Dadzeasah PE, Ansah C. Spathodea campanulata extract attenuates acetaminophen-induced hepatic injury in mice. Int J Pharm Sci Drug Res, 2013; 5:158-64.

Das MP, Dhanabalan R, Doss A. In vitro antibacterial activity of two medicinal plants against bovine udder isolated bacterial pathogens from dairy herds. Ethnobot Leafl, 2009; 13:152-8.

Dhanabalan R, Doss A, Jagadeeswari M, Karthic R. Preliminary phytochemical screening and antimalarial studies of Spathodea campanulatum P. Beauv leaf extracts. Ethnobot Leafl, 2008; 12:811-9.

Dhanabalan $\mathrm{R}$, Palaniswamy $\mathrm{M}$, Devakumar J. In vitro cytotoxicity and anticancer activity of four folklore medicinal plants used among tribal communities of Western Ghats, Coimbatore, Tamil Nadu. Drug Invent Today, 2014; 6:751-9.

Dhanabalan R, Doss A, Balachandar S. In vitro phytochemical screening and antibacterial activity of organic leaf extracts of Spathodea campanulata $\mathrm{P}$. Beauv against hospital isolated bacterial strains. Ethnobot. Leafl, 2008; 12:1022-8.

Diallo A, Traore MS, Keita SM, Balde MA, Keita A, Camara M, Van Miert S, Pieters L. Management of diabetes in Guinean traditional medicine: an ethnobotanical investigation in the coastal lowlands. J Ethnopharmacol, 2012; 144:353-61; doi:10.1016/j.jep.2012.09.020

Disengomoka I, Delaveau P. Medicinal plants used for child's respiratory diseases in Zaire. Part I. J Ethnopharmacol, 1983; 8:257-63; doi:10.1016/0378-8741(83)90063-6

Eid HH, Shehab NG, El Zalabani SM. GC-MS profile and cytotoxicity of the hydrodistilled and extracted volatiles of the buds and flowers of Spathodea campanulata P. Beauv. J Biol Act Prod from Nat, 2014; 4:196-208; doi:10.1080/22311866.2014.936899

Elusiyan AC, Ani NC, Adewunmi CO, Olugbade TA. Distribution of iridiod glucosides and anti-oxidant compounds in Spathodea campanulata parts. African J Tradit Complement Altern Med, 2011; 8:27-33.

Emmanuel M, Didier, D. Medicinal plant knowledge of ethnic groups in Douala town, Cameroon. Am J Food Nutr, 2011; 1:178-84. doi:10.5251/ajfn.2011.1.4.178.184

Flowers of India. African tulip tree. 2021. Available via http:// www.flowersofindia.net/catalog/slides/African\%20Tulip\%20Tree.html
Focho DA, Newu MC, Anjah MG, Nwana FA, Ambo FB Ethnobotanical survey of trees in Fundong, Northwest Region, Cameroon. J Ethnobiol Ethnomed, 2009a; 5:17; doi:10.1186/1746-4269-5-17

Focho DA, Ndam WT, Fonge BA. Medicinal plants of Aguambu - Bamumbu in the Lebialem highlands, southwest province of Cameroon. Afr J Pharm Pharmacol, 2009b; 3:1-13.

Fokou PVT, Nyarko AK, Appiah-Opong R, Tchokouaha Yamthe, LR, Addo P, Asante IK, Boyom FF. Ethnopharmacological reports on anti-Buruli ulcer medicinal plants in three West African countries. J Ethnopharmacol, 2015; 172:297-311; doi:10.1016/j.jep.2015.06.024

Fokou PVT, Kissi-Twum AA, Yeboah-Manu D, Appiah-Opong $\mathrm{R}$, Addo P, Yamthe LRT, Mfopa AN, Boyom FF, Nyarko AK. In vitro activity of selected west African medicinal plants against Mycobacterium ulcerans disease. Molecules, 2016; 21:445; doi:10.3390/molecules21040445

Fongod A, Veranso M, Libalah M. Identification and use of plants in treating infertility in human females in Fako Division, Cameroon Glob J Res Med Plants Indig Med, 2013; 2:724-37.

Fongod AGN, Ngoh LM, Veranso MC. Ethnobotany, indigenous knowledge and unconscious preservation of the environment: an evaluation of indigenous knowledge in South and Southwest Regions of Cameroon. Int J Biodivers Conserv, 2014; 6:85-99; doi:10.5897/ijbc2013.0637

Franco DP, Guerreiro JC, Ruiz MG, Da Silva RMG. Evaluation of insecticide potential of Spathodea campanulata (Bignoniaceae) nectar on Sitophilus Zeamais (Coleoptera: Curculionidae). Rev Colomb Entomol, 2015; 41:63-7.

Gormann R, Kaloga M, Kolodziej H. Novel flavonoids from leaf extracts of Markhamia acuminata and Spathodea campanulata. Planta Med, 2006; 72:35; doi:10.1055/s-2006-949835

Gouda YG. Iridoids from Spathodea campanulata P. Beauvais leaves. Nat Prod Commun, 2009a; 4:753-6.

Gouda YG. Flavonoids and phenylpropanoids from Spathodea campanulata P. Beauvais leaves. Bull Pharm Sci, 2009b; 32:301-9; doi:10.21608/bfsa.2009.63500

Hamill FA, Apio S, Mubiru NK, Bukenya-Ziraba R, Mosango M, Maganyi OW, Soejarto DD. Traditional herbal drugs of Southern Uganda, II: literature analysis and antimicrobial assays. J Ethnopharmacol, 2003; 84:57-78; doi:10.1016/S0378-8741(02)00289-1

Hareesh AR, Harsha R, Ahmed MG, Satish Kumar BP, Thammanna Gowda SS, Joshi V, Chethan IA. Nitric oxide and superoxide radical scavenging activity of flower of Spathodea campanulata P. Beauv. Invent Rapid Ethnopharmacol, 2010a; 1:2-4.

Hareesh AR, Kowti R, Harsha R, Ahmed MG, Satish Kumar BP, Dinesha R, Mohammed IA, Thammanna Gowda SS. In vitro antioxidant and free radicals scavenging activity of flower of Spathodea campanulata P. Beauv. Int J Pharm Sci, 2010b; 2:508-14.

Heim S, Guarnier F, Ferreira D. Antioxidant activity of Spathodea campanulata (Bignoneaceae) extracts. Rev Bras Plants Med, 2012; 14:287-92.

Henry SG, Francis A, Kofi A. Ethnobotanical survey of medicinal plants used for the treatment of diarrhoea and skin ulcer in the Brong Ahafo region of Ghana. J Med Plants Res, 2013; 7:3280-5; doi:10.5897/ JMPR2013.5170

Herrera I, Brice L, Grillo R. Methodology for the artificial inoculation with Ceratocystis sp. for the control of Spathodea campanulata Beauv. Centro Agric, 2002; 29:56-8.

Ilodigwe EE, Akah PA, Nworu CS. Anticonvulsant activity of ethanol leaf extract of Spathodea campanulata P. Beauv (Bignoniaceae). J Med Food, 2010a; 13:827-33; doi:10.1089/jmf.2009.0144

Ilodigwe EE, Akah PA, Okoye TC, Omeje EO. Anticonvulsant effects of a glycoside isolated from the leaf of Spathodea campanulata $\mathrm{P}$ Beauv. J Med Plants Res, 2010b; 4:1895-900; doi:10.5897/JMPR10.360

Ilodigwe EE, Akah PA, Nworu CS. Evaluation of the acute and subchronic toxicities of ethanol leaf extract of Spathodea campanulata P. Beauv. Int J Appl Res Nat Prod, 2010c; 3:17-21.

Ilodigwe EE, Akah PA. Spathodea Campanulata: An experimental evaluation of the analgesic and anti-inflammatory properties of a traditional remedy. Asian J Med Sci, 2009; 1:35-8. 
Ior LD, Otimenyin SO, Okwori VA, Umar DM, Azila JJ. Ethnobotanical survey of plants used in the management of mental illnesses in some selected local government areas of Plateau State, Nigeria. J Pharmacogn Phyther, 2017; 9:146-56; doi:10.5897/jpp2017.0464

IUCN. The IUCN red list of threatened species version 2020-1. 2020. Available via https://www.iucnredlist.org/ species/49196213/49196223

Iyamah PC, Idu M. Ethnomedicinal survey of plants used in the treatment of malaria in Southern Nigeria. J Ethnopharmacol, 2015; 173:287-302; doi:10.1016/j.jep.2015.07.008

Jeruto P, Lukhoba C, Ouma G, Otieno D, Mutai C. An ethnobotanical study of medicinal plants used by the Nandi people in Kenya. J Ethnopharmacol, 2008; 116:370-6; doi:10.1016/j.jep.2007.11.041

Kamatenesi-Mugisha M, Oryem-Origa H, Odyek O, Makawiti DW. Medicinal plants used in the treatment of fungal and bacterial infections in and around Queen Elizabeth Biosphere Reserve, western Uganda. Afr J Ecol, 2008; 46:90-7; doi:10.1111/j.1365-2028.2008.00935.x

Khatri S, Goswami RB, Jain S. Phytochemical screening and evaluation of antiulcer activity of ethanolic extract of Spathodea campanulata leaves. J Drug Deliv Ther, 2019; 9:1012-5.

Kibuuka MS, Anywar G. Medicinal plant species used in the management of hernia by traditional medicine practitioners in central Uganda. Ethnobot Res Appl, 2015; 14:289-98; doi:10.17348/era.14.0.289298

Kihdze TJ, Mayowa AA, Joseph O, Joseph Oc E, Ghaife TG, Bulus A, Van Aerschot A, Laekeman G, Ganafa AA. Phytochemical and antidiabetic evaluation of the methanolic stem bark extract of Spathodea campanulata (P. Beauv.) Bignoniaceae. Pharmacogn J, 2016; 8:243-9; doi:10.5530/pj.2016.3.12

Killedar SG, Kope KI, Sangle SB, Tamboli MS. Standardization and antimicrobial activity of watery fluid at floral base of Spathodea campanulata (Pal). Asian J Pharm Anal, 2011; 1:19-21.

Koffi N, Edouard KK, Kouassi K, Edouard KK, Kouassi K. Ethnobotanical study of plants used to treat diabetes, in traditional medicine, by Abbey and Krobou people of Agboville (Cote-d'Ivoire). Am J Sci Res, 2009; 4:45-58

Komlaga G, Agyare C, Dickson RA, Mensah MLK, Annan K, Loiseau PM, Champy P. Medicinal plants and finished marketed herbal products used in the treatment of malaria in the Ashanti region, Ghana. J Ethnopharmacol, 2015; 172:333-46; doi:10.1016/j.jep.2015.06.041

Kona S, Rahman A. Inventory of medicinal plants at Mahadebpur Upazila of Naogaon district, Bangladesh. Appl Ecol Environ Sci, 2016; 4:75-83.

Kowti R, Harsha R, Ahmed MG, Hareesh AR, Thammanna Gowda SS, Dinesha R, Satish Kumar BP, Irfan Ali M. Antimicrobial activity of ethanol extract of leaf and flower of Spathodea campanulata P. Beauv. Res J Pharm Biol Chem Sci, 2010; 1:691-8.

Kowti R, Joshi V, Dabadi P, Thammanna GS, Satish BP, Dinesha R. Antioxydant activity of Spathodea campanulata in prevention of $\mathrm{t} \mathrm{BOOH}$ and $\mathrm{H}_{2} \mathrm{O}_{2}$ induced DNA damage. Int J Curent Pharm Res, 2011; 3:87-9.

Krishnaveni M, Amsavalli L, Chandrasekar R, Madhaiyan P, Durairaj S. Antioxidant activity of plants at Govt. College of Engineering campus, Salem, Tamil Nadu, India. Int J Pharm Sci Rev Res, 2013; 21:160-3.

Kuete V, Tchinda CF, Mambe FT, Beng VP, Efferth T. Cytotoxicity of methanol extracts of 10 Cameroonian medicinal plants towards multi-factorial drug-resistant cancer cell lines. BMC Complement Altern Med, 2016; 16:267.

Kumar A. Evaluation of phytochemical screening \& antibacterial activity of aqueous, ethanol extracts of medicinal plants against few common microorganisms. V Care Life Sci J, 2012; 2:17-28.

Kumar S, Dash D. Flora of Nandan Kanan sanctuary: medicinal plants with their role in health care. Int J Pharm Life Sci, 2012; 3:1631-42.

Kumar S, Gajbhiye RL, Besra SE. Apoptosis inducing activity of bark extract of Spathodea campanulata on human leukemia cell lines U937, K562 \& HL60 cell lines via caspase cascade. Int J Pharm Sci Rev Res, 2020a; 64(1):114-22; doi:10.47583/ijpsrr.2020.v64i01.022
Kumar S, Gajbhiye RL, Besra SE. Apoptosis inducing potentiality of Spathodea campanulata bark against hepatocellular carcinoma: HEPG2 cells. World J Pharm Res, 2020b; 9(8)1578-94; doi:10.20959/wjpr2020818129

Labrada R, Medina AD. The invasiveness of the african tulip tree, Spathodea campanulata beauv. Biodiversity, 2009; 10:79-82; doi:10.1 080/14888386.2009.9712848

Lacroix D, Prado S, Kamoga D, Kasenene J, Namukobe J, Krief S, Dumontet V, Mouray E, Bodo B, Brunois F. Antiplasmodial and cytotoxic activities of medicinal plants traditionally used in the village of Kiohima, Uganda. J Ethnopharmacol, 2011; 133:850-5; doi:10.1016/j. jep.2010.11.013

Lamaeswari G, Anuradha R. Analgesic effects of the ethanolic extract of flowers of Spathodea campanulata studied in Albino mice. Int Res J Pharm Appl Sci, 2013a; 3:8-12.

Lamaeswari G, Anuradha R. In vitro antioxidant activity of ethanolic flower extract of Spathodea campanulata P. Beauv. Int J Biol Pharm allied Sci, 2013b; 2:2130-6.

Oladunmoye MK, Kehinde FY. Ethnobotanical survey of medicinal plants used in treating viral infections among Yoruba tribe of South Western Nigeria. African J Microbiol Res, 2011; 5:2991-3004; doi:10.5897/ajmr10.004

Magnibou L, Nyemb J, Magne C, Mbougnia J, Leutcha B, Henoumont C. Chemical constituents of Spathodea campanulata (Bignoniaceae), their antimicrobial and antioxidant activities. Nat Prod Chem Res, 2021; 9(4):1-7.

Mahanoa MFKAO, Bwirondea FM, Amanib AC, Mangambub JD, Nyakabwab DS, Wimbac LK, Tshibangud DST, Ngboluad KN, Kambalee JK, Mpianad PT. Ethnopharmacological survey of plants used against diabetes in Bukavu city (DR Congo). J Ethnobiol Tradit Med, 2013; 119:538-46.

Makinde JM, Amusan OOG, Adesogan EK. The antimalarial activity of Spathodea campanulata stem bark extract on Plasmodium berghei berghei in mice. Planta Med, 1988; 54:122-5; doi:10.1055/s-2006-962367

Makinde JM, Adesogan EK, Amusan OOG. The schizontocidal activity of Spathodea campanulata leaf extract on Plasmodium berghei berghei in mice. Phyther Res, 1987; 1:65-8; doi:10.1002/ptr.2650010205

Makindet JM, Amusan OOG, Adesogan EK. The antimalarial activity of chromatographic fractions of Spathodea campanulata stem bark extracts against Plasmodium berghei berghei in mice. Phyther Res, 1990; 4:53-6; doi:10.1002/ptr.2650040204

Malan DF, Neuba DFR, Kouakou KL. Medicinal plants and traditional healing practices in ehotile people, around the aby lagoon (eastern littoral of Côte d'Ivoire). J Ethnobiol Ethnomed, 2015; 11:21; doi:10.1186/s13002-015-0004-8

Manya MH, Keymeulen F, Ngezahayo J, Bakari AS, Kalonda ME, Kahumba BJ, Duez P, Stevigny C, Lumbu SJB. Antimalarial herbal remedies of Bukavu and Uvira areas in DR Congo: an ethnobotanical survey. J Ethnopharmacol, 2020; 249:112422; doi:10.1016/j.jep.2019.112422

Mbosso EJT, Ngouela S, Nguedia JCA, Penlap Bengs V, Rohmer M, Tsamo E. Spathoside, a cerebroside and other antibacterial constituents of the stem bark of Spathodea campanulata. Nat Prod Res, 2008; 22:296304; doi:10.1080/14786410701766281

Mbosso Teinkela JE, Assob Nguedia JC, Meyer F, Vouffo Donfack E, Lenta Ndjakou B, Ngouela S, Tsamo E, Adiogo D, Guy Blaise Azebaze A, Wintjens R. In vitro antimicrobial and anti-proliferative activities of plant extracts from Spathodea campanulata, Ficus bubu, and Carica papaya. Pharm Biol, 2016; 54:1086-95; doi:10.3109/13880209.20 15.1103273

Melendez PA, Capriles VA. Antibacterial properties of tropical plants from Puerto Rico. Phytomedicine, 2006; 13:272-6; doi:10.1016/j. phymed.2004.11.009

Mensah AY, Houghton PJ, Dickson RA, Fleischer TC, Heinrich $\mathrm{M}$, Bremner P. In vitro evaluation of effects of two Ghanaian plants relevant to wound healing. Phyther Res, 2006; 20:941-4; doi:10.1002/ptr 
Moronkola DO, Olaoluwa OO, Oladosu IA, Aboaba SA, Aiyelaagbe OO. Phytochemical and antimicrobial activities of extracts from six medicinal plants utilized as antimalarials in ethno-medicine. Pharm Chem J, 2018; 5:52-61.

Moshi MJ, Otieno DF, Mbabazi PK, Weisheit A. Ethnomedicine of the Kagera region, north western Tanzania. Part 2: The medicinal plants used in Katoro Ward, Bukoba District. J Ethnobiol Ethnomed, 2010; 6:19; doi:10.1186/1746-4269-6-19

Mukungu N, Abuga K, Okalebo F, Ingwela R, Mwangi J. Medicinal plants used for management of malaria among the Luhya community of Kakamega East sub-County, Kenya. J Ethnopharmacol, 2016; 194:98-107; doi:10.1016/j.jep.2016.08.050

Musinguzi D, Tumushabe A, Sekabira K, Basamba TA, Byarugaba D. Medicinal plants use in and around Kalinzu central forest reserve, Western Uganda. J Med Plants Stud, 2017; 5:44-9.

Nazif NM. Phytochemical and antioxidant activity of Spathodea campanulata P. Beauvois. Growing in Egypt. Nat Prod Sci, 2007; 13:11-6.

Ngnameko CR, Marchetti L, Zambelli B, Quotadamo A, Roncarati D, Bertelli D, Njayou FN, Smith SI, Moundipa PF, Costi MP, Pellati F. New insights into bioactive compounds from the medicinal plant Spathodea campanulata P. Beauv. and their activity against Helicobacter pylori. Antibiotics, 2020; 9:258; doi:10.3390/antibiotics 9050258

Ngane RAN, Mogtomo MLK, Tiabou AT, Nana HM, Chieffo PRM, Bounou ZM, Etame RME, Ndifor F, Biyiti L, Zollo PHA. Ethnobotanical survey of some Cameroonian plants used for treatment of viral diseases. African J Plant Sci, 2011; 5:15-21.

Ngouela S, Nyasse B, Tsamo E, Sondengam BL, Connolly JD. Spathodic acid: a triterpene acid from the stem bark of Spathodea campanulata. Phytochemistry, 1990; 29:3959-61; doi:10.1016/00319422(90)85376-Q

Ngouela S, Tsamo E, Sondengam B. Extractives from Bignoniaceae: constituents of the stem bark of Spathodea campanulata. Planta Med, 1988; 54:476-6; doi:10.1055/s-2006-962516

Ngouela S, Tsamo E, Sondengam BL, Connolly JD. Spathodol, a new polyhydroxysterol from the leaves of Spathodea campanulata. J Nat Prod, 1991; 54:873-6; doi:10.1021/np50075a023

Niyonzima G, Laekeman G, Witvrouw M, Van Poel B, Pieters L, Paper D, De Clercq E, Franz G, Vlietinck AJ. Hypoglycemic, anticomplement and anti-HIV activities of Spathodea campanulata stem bark. Phytomedicine, 1999; 6:45-9; doi:10.1016/S0944-7113(99)80034-8

Niyonzima G, Laekeman GM, Scharpe S, Mets T, Vlietinck AJ. Hypoglycemic activity of Spathodea campanulata bark decoctions on streptozotocin-diabetic mice. Planta Med, 1990; 56:682; doi:10.1055/s-2006-961354

Niyonzima G, Pieters L, Balde AM, Claeys M, Laekeman GM, Vlietinck AJ. Isolation of 6-O-caffeoylcatalpol and some other compounds from Spathodea campanulata. Planta Med, 1991; 57:A85-6; doi:10.1055/s-2006-960359

Niyonzima G, Scharpe S, Van Beeck L, Vlietinck AJ, Laekeman GM, Mets T. Hypoglycaemic activity of Spathodea campanulata stem bark decoction in mice. Phyther Res, 1993; 7:64-7; doi:10.1002/ptr.2650070115

Noumi E, Fozi FL. Ethnomedical botany of epilepsy treatment in Fongo-Tongo village, Western Province, Cameroon. Pharm Biol, 2003; 41:330-9; doi:10.1076/phbi.41.5.330.15944

Noumi E. Treating fibromyoma with herbal medicines in South Cameroon. Indian J Tradit Knowl, 2010; 9:736-41.

Nwafor F, Tchimene M, Onyekere P, Nweze N, Orabueze C. Ethnobiological study of traditional medicine practices for the treatment of chronic leg ulcer in South eastern Nigeria. Indian J Tradit Knowl, 2018; $17: 34-42$

Nwauzoma AB, Dappa MS. Ethnobotanical studies of Port Harcourt Metropolis, Nigeria. ISRN Bot, 2013; 2013:1-11; doi:10.1155/2013/829424

Nyamukuru A, Tabuti JRS, Lamorde M, Kato B, Sekagya Y, Aduma PR. Medicinal plants and traditional treatment practices used in the management of HIV/AIDS clients in Mpigi District, Uganda. J Herb Med, 2017; 7:51-8; doi:10.1016/j.hermed.2016.10.001
Odongo E, Mungai N, Mutai P, Karumi E, Mwangi J, Omale J. Ethnobotanical survey of medicinal plants used in Kakamega County, western Kenya. Appl Med Res, 2018; 4:22-40; doi:10.5455/ amr.20180315095706

Offoumou M, Kipre G, Zirihi G, N'guessan K, Silue K, Bouable G, Djaman A, Grellier P. Ethnopharmacology study and phytochemical screening of twelve Ivorian antimalaria plants. Int J Recent Adv Multidiscip Res, 2017; 04:2441-3.

Ofori-Kwakye K, Kwapong AA, Adu F. Antimicrobial activity of extracts and topical products of the stem bark of Spathodea campanulata for wound healing. African J Tradit Complement Altern Med, 2009; 6:168 74; doi:10.4314/ajtcam.v6i2.57089

Ofori-Kwakye K, Kwapong AA, Bayor MT. Wound healing potential of methanol extract of Spathodea campanulata stem bark formulated into a topical preparation. African J Tradit Complement Altern Med, 2011; 8:218-23; doi:10.4314/ajtcam.v8i3.65280

Omale JM, Mutai P, Njogu P, Mukungu N, Mwangi J, Odongo E. Ethnobotanical survey of medicinal plants used in Emuhaya Subcounty, Vihiga County in Western Kenya. Appl Med Res, 2020; 7:6-25.

Osei-Djarbeng S, Agyekum-Attobra E, Nkansah R, Solaga, D, Osei-Asante S, Owusu-Dapaah G. Medicinal plants constituting antimalarial herbal preparations in the ghanaian market. Br J Pharm Res, 2015; 5:153-62; doi:10.9734/bjpr/2015/14896

Palande N. Acute oral toxicity study of extract of Spathodea campanulata bark in wistar rats. J Pharm Sci Biosci Res, 2015; 5:613-6.

Parekh J, Chanda S. In vitro screening of antibacterial activity of aqueous and alcoholic extracts of various Indian plant species against selected pathogens from Enterobacteriaceae. Afr J Microbiol Res, 2007; $1: 92-9$.

Parekh J, Chanda SV. Antibacterial activity of aqueous and alcoholic extracts of 34 Indian medicinal plants against some Staphylococcus species. Turkish J Biol, 2008; 32:63-71.

Patil S, Patil V, Ghodke D, Kondawar M, Naikwade N, Magdum C. Formulation of gel and its UV protective study of some medicinal flowers. Asian J Pharm Anal, 2011; 1:34-5.

Patil V, Patil S, Kondawar M, Naikwade N, Magdum C. Study of methanolic extract of flower of Spathodea campanulata L. as an anti-solar Int J Green Pharm, 2009; 3:248-9; doi:10.4103/0973-8258.56285

Pianaro A, Pinto JP, Ferreira DT, Ishikawa NK, Braz-Filho R. Iridoid glucoside and antifungal phenolic compounds from Spathodea campanulata roots. Semina, 2007; 28:251-6.

Prashanth Kumar GM, Shiddamallayya N. Survey of wild medicinal plants of Hassan district, Karnataka. J Med Plants Stud, 2016; 4:91-102.

Priyadarshini ES, Ragan A. Survey on folklore medicinal plants knowledge of inhabitants of Khammam District, Telangana, India. Ann Plant Sci, 2019; 8:3583-90.

Rai K, Pathan S, Dharamdasani L, Nair P, Bodhankar P. Synthesis of silver nanoparticle from Spathodea campanulata leaf extract and study of its antimicrobial and antioxidant activity. Int J Heal Sci Res, 2017; 7:155-64.

Rivera LW, Aide TM. Forest recovery in the Karst region of Puerto Rico. For Ecol Manage, 1998; 108:63-75; doi:10.1016/S03781127(97)00349-6

Roger T, Pierre-Marie M, Igor VK, Patrick VD. Phytochemical screening and antibacterial activity of medicinal plants used to treat typhoid fever in Bamboutos division, West Cameroon. J Appl Pharm Sci, 2015; 5:034-49; doi:10.7324/JAPS.2015.50606

Sangeetha S, Meenakshi S, Akshaya S, Vadivel V, Brindha, P. Evaluation of total phenolic content and antioxidant activity of different solvent extracts of leaf material of Spathodea campanulata P. Beauv. and investigation of their proliferation inhibition potential against EAC cell line. J Appl Pharm Sci, 2016; 6:121-7; doi:10.7324/JAPS.2016.60918

Santos VHM, Minatel IO, Lima GPP, Silva RMG, Chen CYO. Antioxidant capacity and phytochemical characterization of Spathodea campanulata growing in different climatic zones in Brazil. Biocatal Agric Biotechnol, 2020; 24:101536: doi:10.1016/j.bcab.2020.101536 
Santos VHM, Minatel IO, Reco PC, Garcia A, Lima GPP, Silva RMG. Peptide composition, oxidative and insecticidal activities of nectar from flowers of Spathodea campanulata P. Beauv. Ind Crops Prod, 2017; 97:211-7; doi:10.1016/j.indcrop.2016.12.025

Santosh Kumar J, Krishna Chaitanya M, Semotiuk AJ, Krishna $\mathrm{V}$. Indigenous knowledge of medicinal plants used by ethnic communities of South India. Ethnobot Res Appl, 2019; 18:1-112; doi:10.32859/era.18.4.1-112

Saranya M, Mohanraj RS, Dhanakkodi B. Adult emergence and prolong larval duration effects of Spathodea campanulata aqueous leaf extract against the dengue vector Aedes aegypti. Eur J Exp Biol, 2013a; 4:372-80.

Saranya M, Sundaram Mohanraj R, Dhanakkodi B. Larvicidal, pupicidal activities and morphological deformities of Spathodea campanulata aqueous leaf extract against the dengue vector Aedes aegypti. Pelagia Res Libr Eur J Exp Biol, 2013b; 3:205-13.

Satish S, Mohana DC, Raghavendra MP, Raveesha KA. Antifungal activity of some plant extracts against important seed borne pathogens of Aspergillus sp. J Agric Technol, 2007; 3:109-19.

Satish S, Raghavendra MP, Raveesha KA. Evaluation of the antibacterial potential of some plants against human pathogenic bacteria. Adv Biol Res (Rennes), 2008; 2:44-8.

Scogin R. Anthocyanins of the Bignoniaceae. Biochem Syst Ecol, 1980; 8:273-6; doi:10.1016/0305-1978(80)90058-7

Shams KA, Abou-Setta LM, Radwan HM, Nazif NM, Hassan RA, Soliman AMM. Molluscicidal activity and screening of forty Egyptian medicinal plants and determination of the active fractions. Asian J Chem, 2012; 24:3548-52.

Shehab NG, Eid HH, El Zalabani SM. Bioactivity and composition of the flowers of Spathodea campanulata P. Beauv. World J Pharm Res, 2014; 3:213-30.

Shehu MW, Bello I, Abdulkadir N, Shehu A, Jamil SE, Waziri SA. Utilization of medicinal plants used in the management of HIV/AIDS opportunistic infections in Njeru sub-county, buikwe district, Uganda. MOJ Bioequiv Availab, 2018; 5:66-72.

Shiracko N, Owuor BO, Gakuubi MM, Wanzala W. A survey of ethnobotany of the AbaWanga people in Kakamega County, western province of Kenya. Indian J Tradit Knowl, 2016; 15:93-102.

Shukla AN, Srivastava S, Rawat AKS. A survey of traditional medicinal plants of Uttar Pradesh (India) - used in treatment of infectious diseases. Nat Sci, 2014; 11:24-36.

Simbo DJ. An ethnobotanical survey of medicinal plants in Babungo, Northwest Region, Cameroon. J Ethnobiol Ethnomed, 2010; 6:8; doi:10.1186/1746-4269-6-8

Sonibare MA, Osiyemi OA. Morphological and anatomical studies of two medicinal plants: Harrisonia abyssinica Oliv. (Simaroubaceae) and Spathodea campanulata P. Beauv. (Bignoniaceae) and their systematic significance. J Chem Pharm Res, 2012; 4:800-7.

Subramanian SS, Nagarajan S, Sulochana N. Flavonoids of eight Bignoniaceous plants. Phytochemistry, 1972; 11:1499; doi:10.1016/S00319422(00)90115-8

Subramanian SS, Sulochana N, Nagarajan S. Caffeic acid from leaves of Spathodea campanulata. Curr Sci, 1973; 42:403.

Sy GY, Nongonierma RB, Ngewou PW, Mengata DE, Dieye AM, Cisse A, Faye B. Healing activity of methanolic extract of the barks of Spathodea campanulata Beauv (Bignoniaceae) in rat experimental burn model. Dakar Med, 2005; 50:77-81.

Tabuti JRS, Lye KA, Dhillion SS. Traditional herbal drugs of Bulamogi, Uganda: plants, use and administration. J Ethnopharmacol, 2003; 88:19-44; doi:10.1016/S0378-8741(03)00161-2

Tabuti JRS, Kukunda CB, Waako PJ. Medicinal plants used by traditional medicine practitioners in the treatment of tuberculosis and related ailments in Uganda. J Ethnopharmacol, 2010; 127:130-6; doi:10.1016/j. jep.2009.09.035

Takuya K, Toru O. Screening of medicinal plants in Egypt for anti-human immunodeficiency virus type-1 (HIV-1) activity. Jasmr, 2009; $4: 1-8$.
Talla C, Nga N, Ngoupayo J, Mpondo EM. Evaluation of the androgenic properties of the aqueous extract of the trunk bark of Spathodea campanulata P. Beauv. (Bignoniaceae) in male rats. Health Sci Dis, 2021; 22(3):60-8.

Tanayen JK, Ajayi AM, Ezeonwumelu JOC, Oloro J, Tanayen GG, Adzu B, Agaba AG. Antidiabetic properties of an aqueous-methanolic stem bark extract of Spathodea campanulata (Bignoniaceae) P. Beauv. Br J Pharmacol Toxicol, 2014; 5:163-8; doi:10.19026/bjpt.5.5182

Tanayen JK, Ezeonwumelu JOC, Ajayi AM, Oloro J, Tanayen GG, Adzu B, Van Aerschot A, Laekeman G, Agaba AG. Evaluation of the acute and subacute chronic toxicities of the methanolic stem bark extract of Spathodea campanulata (P. Beauv.) Bignoniaceae. Br J Pharmacol Toxicol, 2016; 7:9-19.

Taniguchi M, Chapya A, Kubo I, Nakanishi K. Screening of east african plants for antimicrobial activity. I. Chem Pharm Bull, 1978; 26:2910-3; doi:10.1248/cpb.26.2910

Terashima H, Malasi NM. Ethnobotany of the Lega in the tropical rain forest of eastern Zaire: part one, Zone de Mwenga. Afr Study Monogr Suppl, 1991; 15:1-61.

Tetteh A, Thomford K, Mensah M, Boadu K, Thomford A, Amposah I, Amofa G, Turkson B, Agyemang M, Owusu-Ansah EJ Ghanaian herbal medicines for malaria: an evaluation of the clinical safety and effectiveness of "Time Herbal Mixture" in uncomplicated malaria. Pharmacognosy Res, 2020; 12:71; doi:10.4103/pr.pr_23_19

Tewari D, Samoila O, Gocan D, Mocan A, Moldovan C, Devkota HP, Atanasov AG, Zengin G, Echeverria J, Vodnar D, Szabo B, Crisan G. Medicinal plants and natural products used in cataract management. Front Pharmacol, 2019; 10:1-22; doi:10.3389/fphar.2019.00466

Thampi N, Kumar SN. Evaluation of antimicrobial and free radical scavenging potentials of three valuable medicinal plants-Hyptis suaveolens, Spathodea campanulata and Shorea robusta. J Che Pharm Res, $2015 ; 7: 609-15$.

Titanji VPK, Zofou D, Ngemenya MN. The antimalarial potential of medicinal plants used for the treatment of malaria in Cameroonian folk medicine. African J Tradit Complement Altern Med, 2008; 5:302-21.

Tsabang N, Fongnzossie E, Keumeze V, Jiofack R, Njamen D, Sonwa DJ, Nguelefack BT. Ethnomedical and ethnopharmacological study of plants used by indigenous people of Cameroon for the treatments of diabetes and its signs, symptoms and complications. J Mol Biomark Diagn, $2017 ; 8: 1-5$.

Tsobou R, Mapongmetsem PM, Van Damme P. Medicinal plants used against typhoid fever in Bamboutos division, western Cameroon. Ethnobot Res Appl, 2013; 11:163-74; doi:10.17348/era.11.0.163-174

Tugume P, Kakudidi EK, Buyinza M, Namaalwa J, Kamatenesi M, Mucunguzi P, Kalema J. Ethnobotanical survey of medicinal plant species used by communities around Mabira Central Forest Reserve, Uganda. J Ethnobiol Ethnomed, 2016; 12:5; doi:10.1186/s13002-015-0077-4

Tugume P, Nyakoojo C. Ethno-pharmacological survey of herbal remedies used in the treatment of paediatric diseases in Buhunga parish, Rukungiri District, Uganda. BMC Complement Altern Med, 2019a; 19:353; doi:10.1186/s12906-019-2763-6

Tugume P, Nambejja C, Nyakoojo C, Kamatenesi-Mugisha M. Medicinal plant species used in the treatment of skin diseases in Katabi Subcounty, Wakiso District, Uganda. Ethnobot Res Appl, 2019b; 18:1-17; doi:10.32859/era.18.20.1-17

Uchenna M, Nwozo S, Mohammed B, Garba R, Mohammed Y. Spathodea companulata (African tulip tree) stem and root barks extracts ameliorated n-nitroso diethylamine induced hepatic impairment in male rats. BIOMED Nat Appl Sci, 2021; 1(1):57-65.

Umenwa CE, Ojah EO, Moronkola DO, Adesanwo JK. Phytochemical and antioxidant assessments of three fractions from methanol extract of Spathodea campanulata Beauv. leaves. J Complement Altern Med Res, 2017; 3:1-10.

Vijayasanthi M, Doss A, Kannan KV. Anti-inflammatory activity of Spathodea campanulata P. Beauv. leaves against carrageenan induced paw edema. Elixir Bio Tech, 2015; 78:29450-2. 
Vijayasanthi M, Kannan V. Antimicrobial activities of Delonix elata (Bojer ex Hook.) Raf. and Spathodea campanulata P. Beauv. African J Microbiol Res, 2014; 8:697-701; doi:10.5897/ajmr2013.6192

Villanueva-Partida CR, Casanova-Lugo F, Gonzalez-Valdivia NA, Villanueva-Lopez G, Oros-Ortega I, Cetzal-Ix W, Basu SK. Traditional uses of dispersed trees in the pastures of the mountainous region of Tabasco, Mexico. Agrofor Syst, 2019; 93:383-94; doi:10.1007/s10457-017-0125-2

Wagh A, Butle S, Telang P. In vitro anthelmintic efficacy of Spathodea campanulata P. Beauv. (Bignoniaceae) against Pheretima posthuma. Asian J Pharmacogn, 2019; 3:32-8.

Wagh A, Butle S, Raut D. Isolation, identification, and cytotoxicity evaluation of phytochemicals from chloroform extract of Spathodea campanulata. Future J Pharm Sci, 2021; 7(1):1-8; doi:10.1186/ s43094-021-00205-7

Wagh AS, Butle SR. Plant profile, phytochemistry and pharmacology of Spathodea campanulata P. Beauvais (African Tulip Tree): a review. Int J Pharm Pharm Sci, 2018; 10:1; doi:10.22159/ ijpps.2018v10i5.24096

Waisindye N, Kamatenesi M, Anywar G, Kazibwe F. An ethnobotanical documentation of medicinal plants used by local communities around Kibale National Park, a case of Kanyawara, Kanyansowera and Ibura Villages. Int J Adv Inf Sci Technol, 2016; 5:21-36.
Walugembe J, Iramiot JS, Katuura E. Indigenous knowledge and antibacterial activity of selected herbs used locally to treat common cold in Central Uganda. J Med Plants Res, 2016; 10:520-8; doi:10.5897/ jmpr2016.6181

Yemele MD, Telefo PB, Lienou LL, Tagne SR, Fodouop CSP, Goka CS, Lemfack MC, Moundipa FP. Ethnobotanical survey of medicinal plants used for pregnant womens health conditions in Menoua divisionWest Cameroon. J Ethnopharmacol, 2015; 160:14-31; doi:10.1016/j. jep.2014.11.017

How to cite this article:

Padhy GK. Spathodea campanulata P. Beauv. - A review of its ethnomedicinal, phytochemical and pharmacological profile. J Appl Pharm Sci, 2021; 11(12):017-044. 